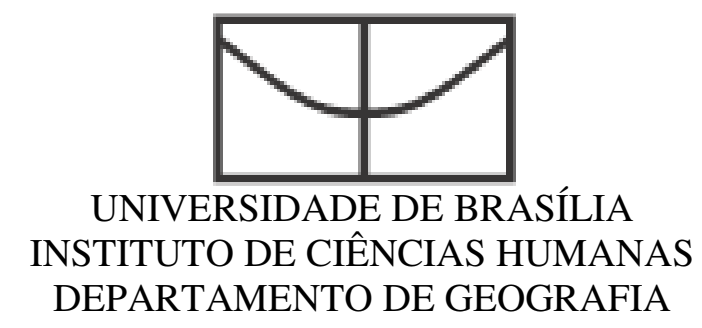

\title{
A VIOLÊNCIA NAS ESCOLAS PÚBLICAS DE SAMAMBAIA: NO CASO DO CENTRO EDUCACIONAL 123
}

GEILSON DOS SANTOS SALES

Brasília

2009 
UNIVERSIDADE DE BRASÍLIA

INSTITUTO DE CIÊNCIAS HUMANAS

DEPARTAMENTO DE GEOGRAFIA

\section{A VIOLÊNCIA NAS ESCOLAS PÚBLICAS DE SAMAMBAIA: NO CASO DO CENTRO EDUCACIONAL 123}

Monografia submetida ao Departamento de Geografia, do Instituto de Ciências Humanas da Universidade de Brasília, e aprovada para a obtenção do título de Bacharel e Licenciado em Geografia.

Banca Examinadora:

Professor Ms. Juvair Fernandes de Freitas - Orientador

Professor Ms. Benjamin Lacerda Júnior - Examinador Professora Dra ${ }^{\mathrm{a}}$ Waleska Valença Manyari - Examinadora

Aluno: Geilson dos Santos Sales

Brasília, junho de 2009 


\section{FICHA CATALOGRÁFICA}

SALES, Geilson dos Santos.

A violência nas escolas públicas de Samambaia: no caso do Centro Educacional 123, 2009. 56

p. Bacharel e Licenciado em Geografia. Monografia de Prática e Pesquisa de Campo 2 de

Geografia. Universidade de Brasília, Instituto de Ciências Humanas, Departamento de Geografia.

I. GEA/IH/UNB

\section{REFERÊNCIA BIBLIOGRÁFICA}

SALES, Geilson dos Santos.

A violência nas escolas públicas de Samambaia: no caso do Centro Educacional 123, 2009. 56 p. Bacharel e Licenciado em Geografia. Monografia de Prática e Pesquisa de Campo 2 de Geografia. Universidade de Brasília, Instituto de Ciências Humanas, Departamento de Geografia.

Brasília - DF.

\section{CESSÃO DE DIREITOS}

É concedido á Universidade de Brasília permissão para reproduzir cópias desta monografia e para emprestar ou vender tais cópias somente para o propósito acadêmico ou científico. 


\section{AGRADECIMENTOS}

- Primeiramente minha família, em especial minha mãe, que sempre me incentivou em todos os passos que dei na vida;

- Ao professor Juvair Fernandes de Freitas pela orientação dada, pela sua compreensão e pelo seu auxílio;

- Aos professores Benjamin Lacerda Júnior e Waleska Valença Manyari por terem aceitado o meu convite para integrar a banca para avaliar o meu trabalho;

- E a todos os funcionários do Departamento de Geografia. 


\section{CITAÇÃO}

"Nunca use violência de nenhum tipo. Nunca ameace com violência de nenhum modo. Nunca sequer tenha pensamentos violentos. Nunca discuta, porque isto ataca a opinião do outro. Nunca critique, porque isto ataca o ego do outro. E o seu sucesso está garantido."

(Mahatma Gandhi) 


\section{SUMÁRIO}

Lista de Mapas .................................................................................... vii

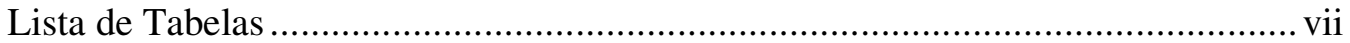

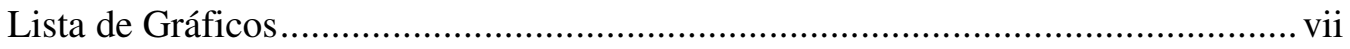

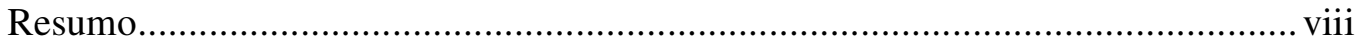

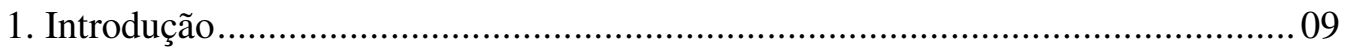

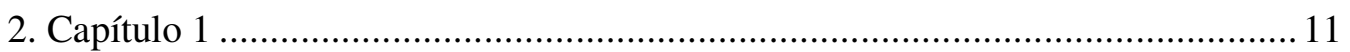

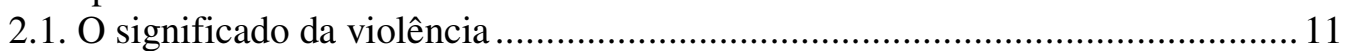

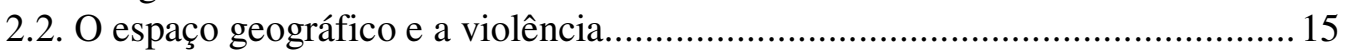

2.2.1. A violência no território e os elementos de análise....................................... 19

2.2.1.1. Os atores ou agentes, o poder e o território .......................................... 23

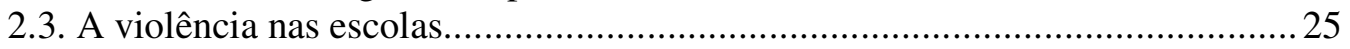

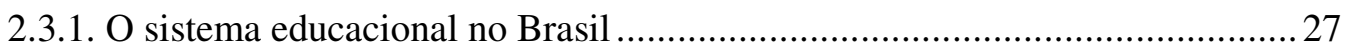

2.3.2. A definição da violência nas escolas ......................................................... 28

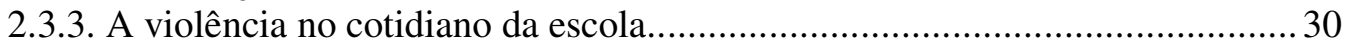

2.4. A violência nas escolas públicas do Distrito Federal..................................... 35

2.4.1. Os tipos de violências encontrados nas entrevistas....................................... 38

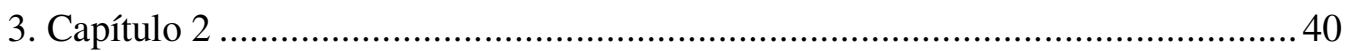

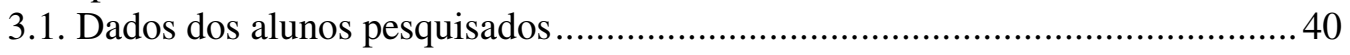

3.2. Os tipos de violência que ocorrem no Centro Educacional 123 em Samambaia41

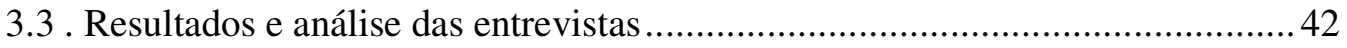

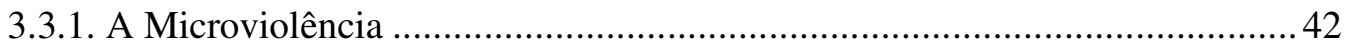

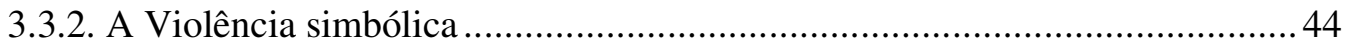

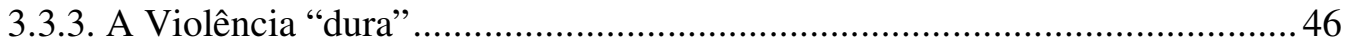

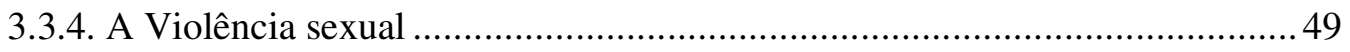

3.4. Os impactos e as conseqüência da violência ...............................................50

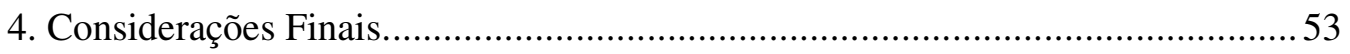

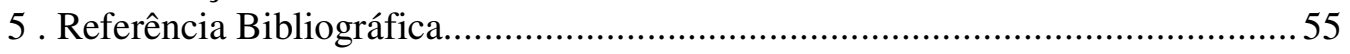




\section{LISTA DE MAPAS}

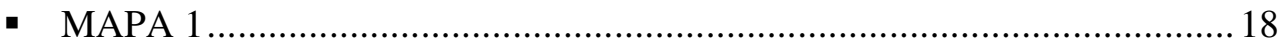

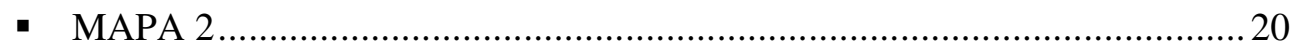

\section{LISTA DE TABELAS}

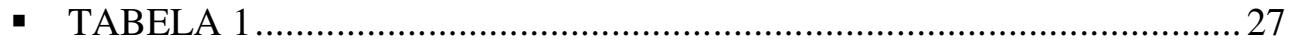

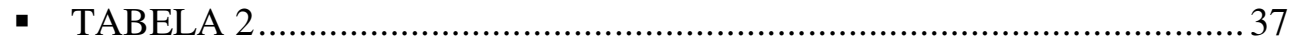

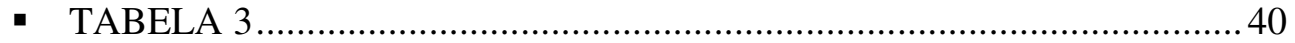

\section{LISTA DE GRÁFICOS}

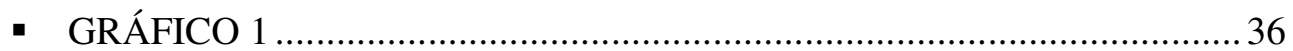

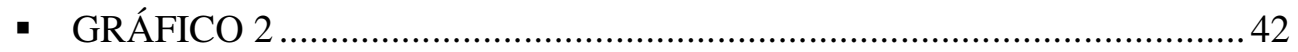

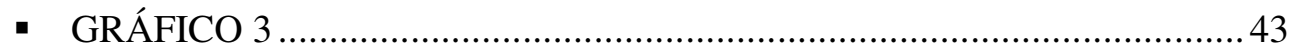

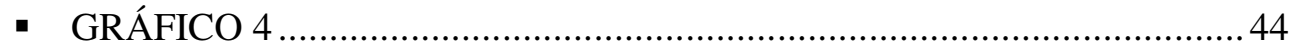

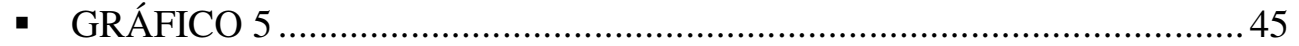

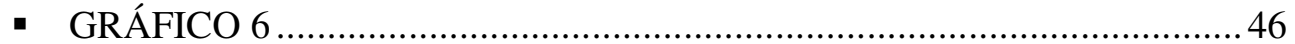

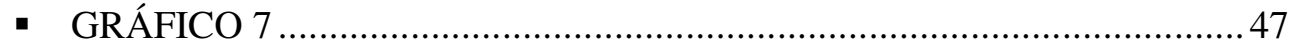

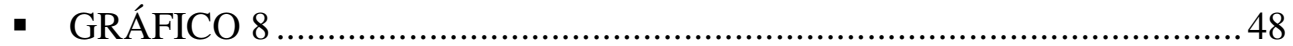

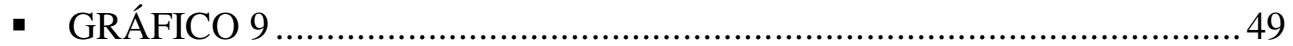

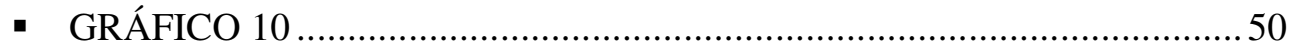

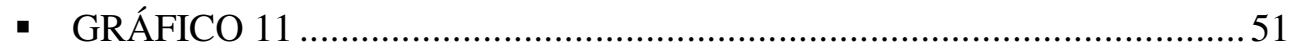




\section{RESUMO}

O trabalho analisa a violência nas escolas como um fenômeno que não é desprezível na transformação do espaço, dentre ele, o espaço escolar. Por isso, sua compreensão e principalmente entender a sua relação com o espaço geográfico.

Para isso, o trabalho foi organizado em 2 capítulos. O primeiro capítulo é composto de conceitos gerais sobre o fenômeno da violência, assim como, é feito uma análise da violência e o espaço geográfico, ou seja, como eles se relacionam, levando em consideração os atores ou agentes, que agem no território; o poder que esses atores possuem e modificam o espaço; e o território, onde ocorrem as ações.

Ainda no primeiro capítulo é feita a análise e compreensão da violência na escola, ou seja, os conceitos, as causas e principalmente as consequiências que a violência na escola ocasiona. É feito, também no primeiro capítulo, uma análise de uma pesquisa feita pela Secretaria de Educação do Distrito Federal - SEDF, no qual avalia a percepção da violência nas escolas públicas do Distrito Federal. A pesquisa mostra, ainda, os tipos de violência que mais ocorrem nas escolas públicas do Distrito Federal.

No segundo capítulo é apresentado o resultado e análise de um questionário que foi aplicado no Centro Educacional 123 em Samambaia - CED 123. No qual avalia a percepção da violência naquela escola e identifica os tipos de violência que mais ocorre naquele ambiente escolar. Por último é apresentada a conclusão que o trabalho chegou sobre a violência nas escolas.

Palavras - chave: Espaço, território, violência, violência escolar. 


\section{INTRODUÇÃO}

Vivenciamos em nossa sociedade mudanças sociais, políticas, tecnológicas e culturais freqüentes que desafiam as nossas instituições educacionais. Aliada a essas mudanças, a violência emergiu como um problema para os indivíduos e a sociedade, com suas diferentes manifestações, que cresce descontroladamente e assusta os administradores escolares, constituindo-se em entrave nas relações educacionais.

A escolha do assunto violência nas escolas, em particular a escola pública, é um desafio e uma forma de se aprofundar no conhecimento de suas causas e suas formas de manifestações. No contexto da sociedade, esse enfoque pode ajudar a compreender a complexidade da problemática educacional bem como as dificuldades encontradas pelos professores, pela escola e pela sociedade na busca de soluções para resolver esse problema.

A violência nas escolas, nos dias atuais, é uma realidade vivenciada tanto por profissionais da educação, como pelos próprios estudantes. Todos os dias se ler notícias nos meios de comunicação sobre agressões, ameaças e outras ações violentas praticadas dentro das escolas. $\mathrm{O}$ ambiente escolar, antes considerado lugar protegido, hoje inspira insegurança entre os alunos, professores e diretores, prejudicados com a violência praticada dentro ou no entorno dela.

A sociedade brasileira, por sua vez, vem-se deparando com um aumento da violência nas escolas, sendo diversos os episódios envolvendo agressões verbais, físicos e simbólicos aos membros da comunidade escolar, como os professores e alunos. Fato esse, que despertou as atenções das diversas instâncias governamentais, dos organismos internacionais e da sociedade em geral.

As escolas do Distrito Federal, em particular as públicas, não estão isentas

desse problema. É corriqueiro nos meios de comunicação, informações sobre a violência nas escolas públicas do DF, dentre elas, agressões, ameaças e uso de instrumentos como revólveres na sala de aula. 
Para compreender o fenômeno da violência na escola, o trabalho busca no primeiro capítulo fazer uma análise da violência, buscando os conceitos desse fenômeno numa compreensão mais geral. Ainda no primeiro capítulo são expostos conceitos da violência na escola, buscando compreende-la e analisá-la fazendo uma relação com os elementos de análise da Geografia, como os atores, o poder e o território. No trabalho é apresentada uma pesquisa da Secretaria de Educação do Distrito Federal sobre a percepção da violência nas escolas públicas do DF.

No segundo capítulo é apresentada a pesquisa feita no Centro Educacional 123 em Samambaia, por meio de um questionário com o objetivo de avaliar a percepção dos alunos em relação à violência. Por último é apresentada a conclusão do trabalho e a referência bibliográfica pesquisada.

O objetivo do trabalho é compreender as causas que leva a manifestação da violência na escola e como ela se manifesta no ambiente escolar, assim como saber quais os principais tipos de violência que acontecem dentro da escola.

O trabalho foi apoiado numa pesquisa de campo com 13 perguntas sobre a violência nas escolas. A pesquisa foi realizada no Centro Educacional $123 \mathrm{em}$ Samambaia, com a participação de 45 alunos do Ensino Médio. Esses 45 alunos foram compostos de 15 alunos do $1^{\circ}$ Ano, 15 alunos do $2^{\circ}$ Ano e 15 estudantes do $3^{\circ}$ Ano. $O$ Centro Educacional 123 se localiza entre as quadras 123 e 125 em Samambaia Sul, segundo dados da CODEPLAN (2004), essa região possui um grande número de famílias de baixa renda.

O trabalho também levantou dados estatísticos de instituições como o IBGE, CODEPLAN e órgãos governamentais como o Ministério da Educação e Secretaria de Educação do Distrito Federal. Foram feitos levantamentos bibliográficos para a análise conceitual do fenômeno violência, da violência na escola e do espaço geográfico. 


\section{CAPÍTULO 1}

\section{1 - O significado da violência}

O termo Violência vem do latim violentia, que significa violência, caráter violento ou bravio, força. O verbo violare significa tratar com violência, profanar, transgredir. Tais termos devem ser referidos a vis, que quer dizer força, potência, violência, emprego de força física, mas também quantidade, abundância, essência ou caráter essencial de uma coisa. Mais profundamente, a palavra vis significa a força em ação, o recurso de um corpo para exercer sua força, portanto, a potência, o valor, a força vital.

É encontrada no âmago da noção de violência, a idéia de força, de uma potência natural cujo exercício contra alguma coisa ou contra alguém torna o caráter violento. A idéia de força constitui o seu núcleo central e contribui para fazê-la designar prioritariamente uma gama de comportamentos e de ações físicas.

"Há violência quando, numa situação de interação, um ou vários atores agem de maneira direta ou indireta, maciça ou esparsa, causando danos a uma ou várias pessoas em graus variados, seja em sua integração física, seja em sua integridade moral, em suas posses, ou em participações simbólicas e culturais" (MICHAUD, Yves, 2001, p.10-11). 
Sob uma visão política da violência, (POSTERLI, 2000, p. 102) cita as idéias de Hannah Arendt ${ }^{1}$. A partir da Filosofia Política, Arendt discute a relação de violência e poder. Para ela, o poder - que é inerente a qualquer comunidade política - resulta da capacidade humana para agir em conjunto, o que, por sua vez, requer o consenso de muitos quanto a um curso comum de ação. (POSTERLI, 2000, p. 102) comenta que de acordo com Arendt, poder e violência são termos opostos, ou seja, a afirmação de um significa a ausência do outro, pois é a desintegração do poder que enseja a violência. $O$ autor afirma ainda, que se a violência é diferente de poder, significa que quanto mais violento, menos poderoso é, isso sob a visão política.

Politicamente, com a perda do poder torna-se uma tentação substituí-lo pela violência. $\mathrm{O}$ poder depende de números, a violência depende mais de implementos, ou seja, é mais instrumental. Isso significa, segundo (POSTERLI, 2000, p. 103), que a partir de um cano de uma arma jamais emergirá o poder e sim a violência. A partir das idéias de Arendt, o autor afirma que o poder corresponde à habilidade humana não apenas para agir, mas para agir em concerto, em conjunto. O poder nunca é propriedade de um único indivíduo, mas pertence a um grupo e permanece em existência apenas na medida em que o grupo conserva-se unido, a violência seria a conseqüência da falta de poder.

Enquanto outros autores como o sociólogo (SOUZA, 2001, p. 51), também busca uma explicação do fenômeno violência. Ele faz uma reflexão sobre a violência do século passado, questionando as atrocidades ocorridas na Primeira Guerra Mundial, assim como também, na Segunda Guerra Mundial e logo depois sobre os grandes genocídios que ocorreram ao longo da Guerra-Fria.

O autor não deixa dúvida de que em todos esses atos de violência, sempre esteve presente à participação do Estado. Muitas por questões políticas (poder), outras por questões religiosas, outras por causa das diferenças étnicas. Para o autor, esses problemas caracterizaram a violência no século passado. Mas partindo do passado e chegando ao presente, (SOUZA, 2001, p. 51) aborda uma situação nova, diferente, ou melhor, com o fim da Guerra-Fria e ocorrendo novos arranjos, surge então, uma nova

\footnotetext{
1 - Em a sua obra: Sobre a Violência publica em 1970;
} 
forma de violência, que se processa internamente nos países. Surge uma violência diferente, um fenômeno que para ele é sem nexo, e nem sentido, mas que está muito presente entre os jovens, tanto da classe média alta, que têm acesso às melhores escolas, ou seja, que têm acesso a praticamente a tudo que o dinheiro proporciona; assim como também a violência que ocorre entre os jovens de baixa renda. É a violência do quotidiano, costumeiro, fútil, como ocorre nos estádios de futebol, nas ruas das cidades, como exemplo, o assassinato do índio Galdino² em Brasília no ano de 1997, no qual seus assassinos, jovens de classe média, alegaram que era apenas uma simples "brincadeira".

“Com o fim da bipolaridade bélica Oriente-Ocidente, não desapareceu a violência ordinária, permanente, ressurgindo nas ruas das cidades, nos estádios esportivos. Uma violência costumeira e estendida. A face absurda dessa violência quotidiana, que os meios de comunicação banalizam, como por exemplo, a morte do índio pataxó" (SOUZA, 2001, p.4).

Segundo (ODALIA, 1983, p. 70), que faz uma classificação da violência como Institucionalizada, Social e Política. A Violência Institucionalizada, para o autor, é que no passado como atualmente, os homens sempre morreram de fome, de frio, de miséria, das secas prolongadas e que as doenças e as epidemias continuam a dizimar populações, ou seja, nada disso é novo. A maneira de pensar e agir, institucionaliza a desigualdade social e faz aparecer como natural a distinção entre os homens que possuem e os que não possuem riquezas. Para o autor, a desigualdade social, enquanto violência, não é um fenômeno atemporal, que deve necessariamente atingir todas as formas de sociedades possíveis. Para ele, toda violência é institucionalizada quando se admite explicita ou implicitamente, que uma relação de força é uma relação natural.

\footnotetext{
2 - O índio pataxó Galdino estava dormindo numa parada de ônibus quando foi atacado por jovens de classe média de Brasília, que puseram fogo em seu corpo, o fato ocorreu no ano de 1997 e que dias após o fato, o índio morreu em um hospital da cidade.Os jovens alegaram que era apenas uma brincadeira;
} 
A Violência Social, que é um atributo mais próximo da realidade estrutural da sociedade. As políticas governamentais, o sistema capitalista que se opõe à sociedade, a educação no Brasil que está deteriorada, o desemprego, etc. Tudo isso são formas de violência social.

A Violência Política, que pode ser o assassinato de um político importante criando instabilidade, a invasão de um país por outro, o desaparecimento de dissidentes políticos, a legislação eleitoral que frauda a opinião pública, leis que não permitem às classes sociais, especialmente o operariado organizar sindicatos etc.

Já (PINHEIRO E ALMEIDA, 2003, p. 22) propõem que a ação, produção de dano/destruição e a intencionalidade são elementos constitutivos da violência, ou seja, para os autores, a violência então, seria a ação intencional que provoca dano. Os autores dividem a violência em três grandes categorias. São elas:

\section{1 - A Violência Auto-Infligida}

Que compreende, segundo os autores, o comportamento suicida e o comportamento auto-abusivo. O primeiro abrange pensamentos suicidas e tentativas de suicídio. Enquanto o segundo, o auto-abusivo, corresponde os atos de automutilação;

\section{2 - A Violência Interpessoal}

Para os autores, esse tipo de violência pode ser de dois tipos:

- A violência da família e dos parceiros íntimos, que pode ocorrer dentro de casa, e que estão relacionadas aos abusos contra crianças, contra uma pessoa íntima, contra idosos. A questão da violência contra a mulher entra dentro desse tipo de violência, segundo os autores;

- A violência comunitária, que corresponde geralmente à violência que ocorre fora de casa, entre pessoas que não se conhecem. A violência juvenil, os atos aleatórios de violência, estupros, assim como a violência nas escolas, locais de trabalho, etc. 


\section{3 - A Violência Coletiva}

Para os autores, esse tipo de violência pode ser dividido em violência social, política e econômica. A violência coletiva pode indicar a existência de agendas sociais, como por exemplo, os crimes de ódio cometidos por grupos organizados, os atos terroristas e a violência das multidões. Na violência política, incluem-se as guerras e os conflitos armados, a violência do Estado e os atos semelhantes cometidos por grupos maiores. Já na violência econômica, temos ataques de grupos maiores motivados pelo ganho material, tais como aqueles que objetivam interromper a atividade produtiva, negar o acesso a serviços essenciais ou criar segmentos econômicos (PINHEIRO E ALMEIDA, 2003, p. 24).

De acordo com as idéias dos autores, a questão da violência na escola, poderia ser classificada na categoria da Violência Interpessoal, porque ela envolveria a comunidade, as famílias, já que a escola está inserida dentro da comunidade e possui uma relação direta com as famílias.

2.2 - O espaço geográfico e a violência

Para (FERREIRA E PENNA, 2005, p. 57) a espacialidade é uma categoria geográfica usada por todos os ramos do conhecimento como uma primeira apreensão do fenômeno na busca de sua explicação pelas diferentes especialidades. Com isso, segundo as autoras, o que se pretende é o entendimento da territorialização da violência, ou seja, o Território da Violência ${ }^{3}$, por isso elas trazem primeiro o conceito de território:

\footnotetext{
3 - São os espaços onde concentra altos índices de violência e que possui pouca ou nunca infraestruturas;
} 
"É o espaço concreto em si (com seus atributos naturais e socialmente construídos) que é apropriado, ocupado por um grupo social. A ocupação do território é vista como algo gerador de raízes e identidade. Um grupo não pode mais ser compreendido sem o seu território, no sentido de que a identidade sócio-cultural das pessoas estaria inarredavelmente ligada aos atributos do espaço concreto" (SOUZA, 1995, p.84, apud FERREIRA e PENNA, 2005, p.60).

Os diferentes territórios da cidade não se definem apenas como uma base na qual se formam as identidades que se criam com o território, seja ela a pobreza, a riqueza ou a violência. A abordagem da realidade tem por base a noção de "produção do espaço urbano", na qual o espaço da cidade não é apenas um elemento transitório da sociedade, um receptáculo das relações sociais. As formas espaciais criadas pelos homens - as cidades, os bairros, os guetos, etc - expressam as relações sociais vigentes de acordo com a época em que foram produzidas. A violência nas escolas pode ser considerada como resultado das relações sociais que acontecem no interior dessas instituições, como também, resultados das relações que ocorrem fora dela.

De acordo com (FERREIRA E PENNA, 2005, p. 61), as cidades, transformadas em objetos de consumo, agregam conteúdos sociais às formas construídas que se articulam fortemente para criar territórios urbanos. Então, os espaços passam a ser diferenciados por suas "formas/conteúdos" e não apenas por condições variáveis da natureza e da sociedade. As sociedades ao produzirem seus espaços valorizam ou desvalorizam certas porções do território que vão ser apropriadas por diferentes atores sociais.

A violência costuma ser relacionada à pobreza, à exclusão social, à omissão do Estado, à ausência de serviços públicos urbanos e ao próprio processo de urbanização que cria os enclaves de pobreza e as periferias. Para elas, a complexidade e o crescimento da violência nas cidades têm levado a considerá-la como o resultado da junção de todos esses fatores. Pois, é no território, que esses diferentes aspectos do processo social se articulam, interpenetram-se, completam-se e contradizem-se. Segundo as autoras, admite-se então que a violência também se territorialize. 
O entendimento da violência a partir da visão geográfica deve centrar sua atenção na territorialização, ou seja, a formação do Território da Violência, que muitas vezes pode atingir a escola porque essa insituição está inserida no território. Os locais desvalorizados, marcados pela ausência do Estado e das instituições públicas, abandonados pela lei e no qual o contrato social é rompido, o abrigo da população excluída socialmente e espacialmente periferizada, isso tudo pode tornar-se o habitat do crime organizado, que deles se apropria. Cria-se assim, segundo as autoras, o Território da Violência, reduto do poder do crime organizado que daí comanda sua atuação na cidade e seu exército formado pela população excluída, que habita esses locais. Para as autoras, esses espaços tornados Território da Violência são parte ativa no desenvolvimento do poder constituído pelo crime organizado e pela violência a ele atrelada. Então, para elas, esses espaços alimentam os processos sociais responsáveis pela violência urbana.

O Brasil apresenta uma das sociedades mais desiguais do mundo, com uma grande diferença de renda entre as maiores renda e as menores, que de acordo com o IBGE, essa diferença vem caindo nos últimos anos. O MAPA 1 abaixo mostra a dinâmica da exclusão social no território do Brasil.

De acordo com o MAPA 1 (AMORIM e POCHMANN, 2003) que apresenta a questão da exclusão social no território, o índice mais próximo de zero significa que a exclusão social é forte. Das regiões do Brasil que se destaca no mapa são s regiões do Nordeste e Norte, em que o índice fica no intervalo de 0 a 4 . São essa duas regiões que apresentam os maiores índices de analfabetismos, fome, desnutrição, mortalidade infantil e outros problemas. 


\section{MAPA 1}

\section{Manchas Extremas de Exclusão Social no Brasil}

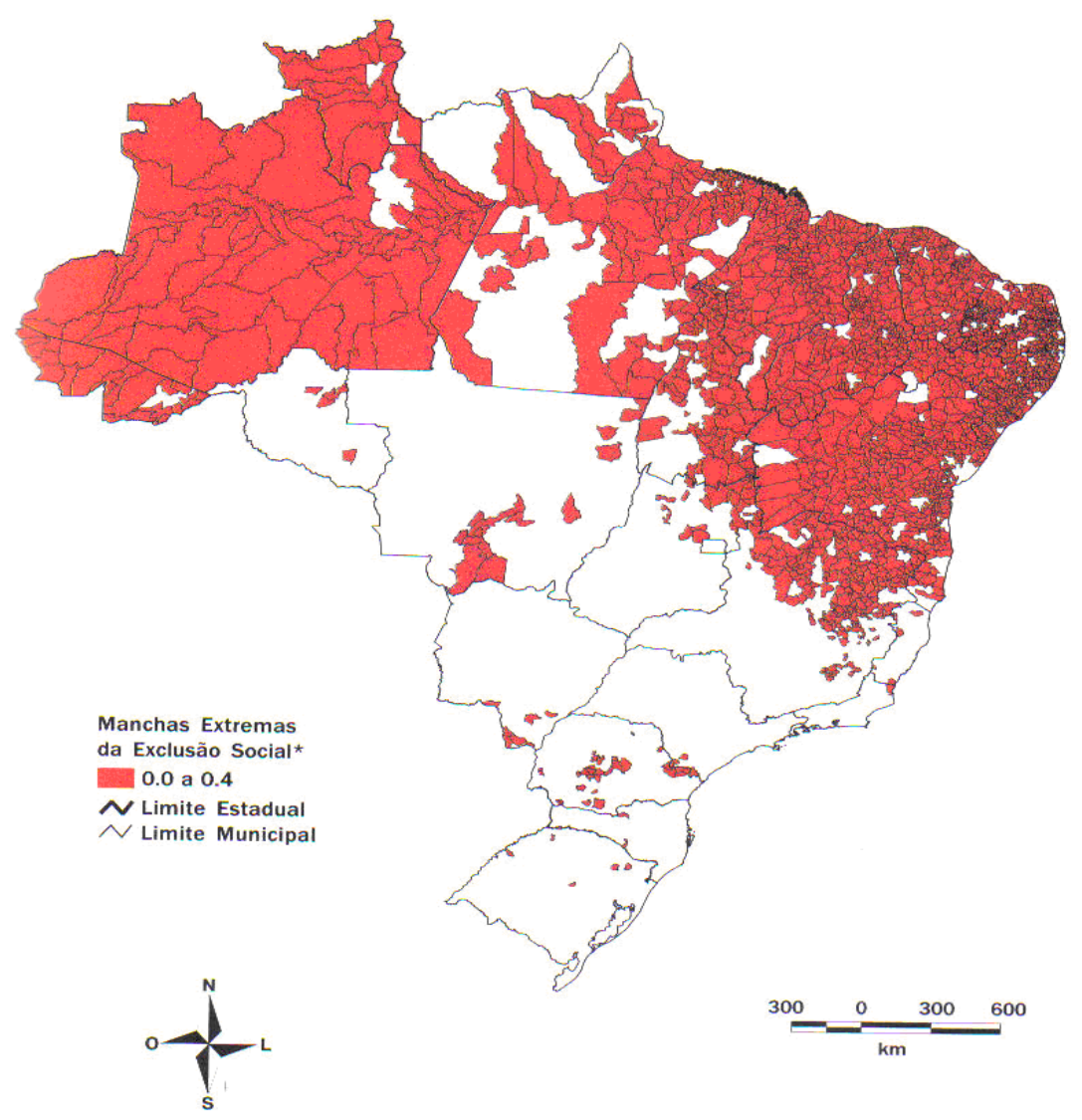

* Somente municípios com menores índices.

Fonte: Atlas da Exclusão no Brasil (AMORIM e POCHMANN, 2003).

Ainda existe o pensamento de relacionar a violência com a questão da exclusão social. Mas muitos estudos comprovam que a violência não está relacionada diretamente com a questão da exclusão, existem outros fatores que influenciam na 
dinâmica da violência. As regiões do Nordeste e Norte são as regiões que possuem os menores índices de violência do Brasil.

Para (SANTOS, 1979, p. 89), o entendimento de toda a dinâmica do espaço nos países em desenvolvimento, deve passar por um estudo da história desses países, que permite revelar uma especificidade de sua evolução em relação às dos países desenvolvidos. Segundo esse autor, essa especificidade aparece claramente na organização da economia, da sociedade e do espaço e, por conseguinte na urbanização que se apresenta como um elemento numa variedade de processos combinados. Pois a violência e a exclusão social podem ser entendidas e avaliadas nessa perspectiva do espaço brasileiro e sua dinâmica. O autor analisa o espaço geográfico como um conjunto indissociável cujo interior é contraditório, formado por sistemas de objetos e sistemas de ações que não acontecem de modo isolado, mas que dependem do fator histórico que lhes dá conformidade (SANTOS, 1996, p. 53). Autores como Hartshorne (apud CHAVES, 2005, p. 32) entende o espaço na forma de um receptáculo que contêm as coisas, ou seja, um conceito abstrato que combina fenômenos naturais e sociais, priorizando a unicidade dele.

2.2.1 - A violência no território e os elementos de análise

Para uma melhor análise da questão da violência, o MAPA 2 (AMORIM e POCHMANN, 2003) abaixo, apresenta esse fenômeno no território do Brasil, no qual mostra que as regiões com os maiores indicadores de violência são as regiões mais ricas, dentre elas o Distrito Federal. Outras como o Sul e Sudeste também apresentam áreas vermelhas, que significa altos índices de violência. 
MAPA 2

\section{Índice de Violência}

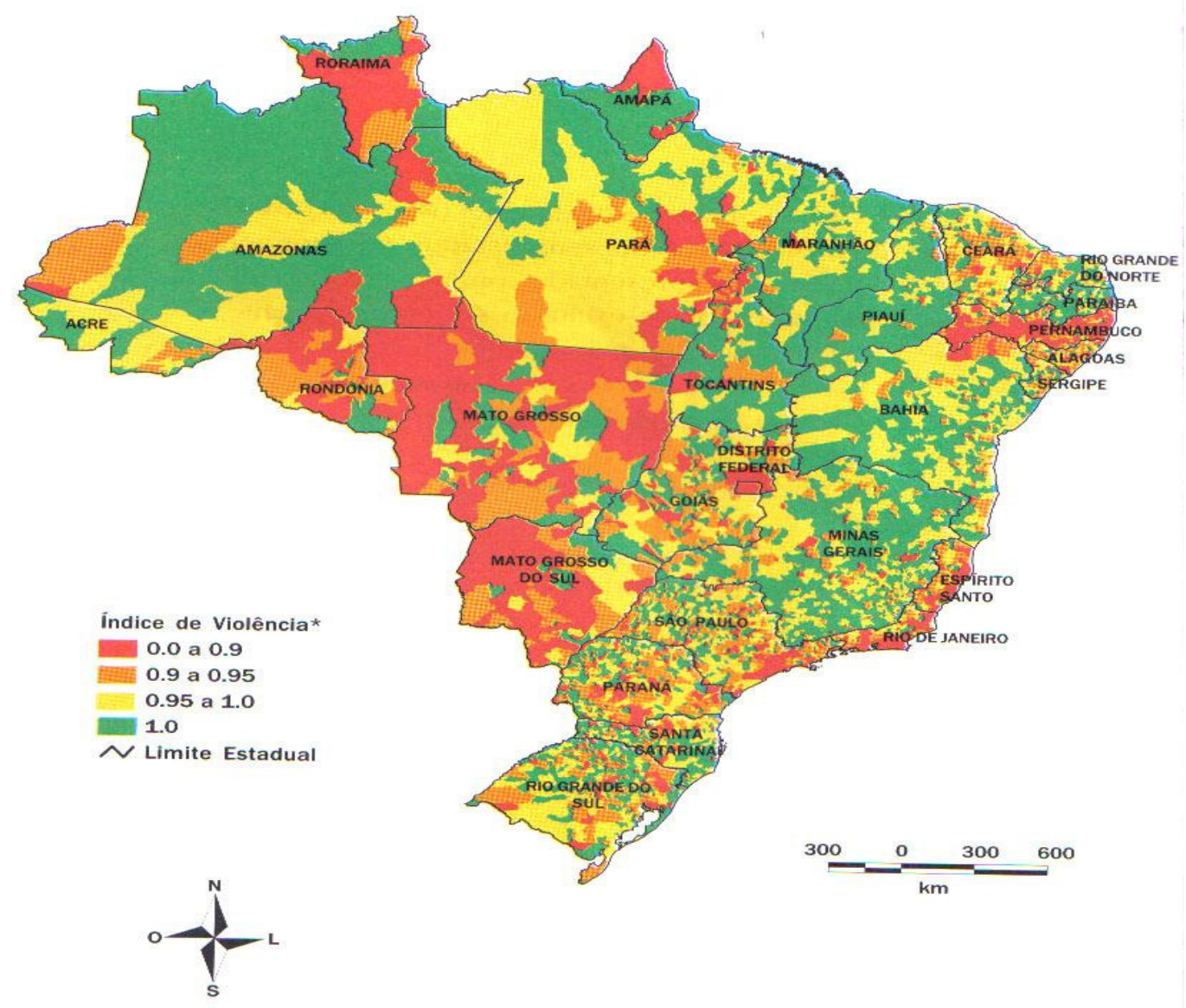

* Quanto maior o índice, melhor a situação social.

Fonte: Atlas da Exclusão Social no Brasil (AMORIM e POCHMANN, 2003).

Esse mapa mostra nas áreas vermelhas os espaços críticos em índice de violência, sendo que na região Centro-Oeste, principalmente no estado de Mato Grosso o mais crítico. No Nordeste seria o estado de Pernambuco, enquanto na região Sudeste, os estados do Rio de Janeiro e Espírito Santo e a capital de São Paulo. O mapa mostra 
a dinâmica da violência no território do Brasil, mas deve-se lembrar que as causas que ocasionam esse fenômeno são diferentes em cada região, como por exemplo, as taxas de violência que acontece em Mato Grosso têm uma relação próxima pela disputa de terra, já que esse estado está situado na região da Amazônia. Essa região é muito cobiçada por grileiros.

Lembrando que o estado de Mato Grosso possui altos índices de desmatamentos da floresta amazônica. Enquanto o estado de São Paulo, Rio de Janeiro e o Distrito Federal, possuem o grande problema da urbanização sem planejamento, que ocasionam em regiões totalmente insalubres, sem infra-estruturas, daí, dando possibilidades para o surgimento de áreas violentas.

Essas mesmas regiões possuem taxas preocupantes de violência nas escolas, segundo dados divulgados na mídia. São situações das mais diversas, como por exemplo, alunos que levam armas para a sala de aula, brigas e agressões entre alunos ou alunos e professores, assim como a questão da depredação do ambiente físico da escola (WAISELFSZ, 2008, p. 81).

A visão sobre a violência é múltipla assim como a busca de conceitos para a sua explicação. Enquanto alguns autores interpretam esse fenômeno como conseqüência das desigualdades sociais que se materializam em uma crescente segregação social. Assim, (STEINBERGER E CARDOSO, 2005, p. 87) afirmam que o grande problema é quando essa explicação seja tomada como absoluta, porque produz um círculo vicioso de "causa-consequência", que para elas provoca "imobilismo e individualismo".

O imobilismo é expresso pela sensação de impotência quando não se vê outro caminho senão adotar medidas paliativas. E individualista ou isolacionista porque é expresso por ações isoladas que transformam bairros, residências e automóveis em verdadeiras prisões, e o desejo de resolver a violência com as próprias mãos. Para as autoras, isso tudo, pode gerar em cobranças de maior atuação do Estado, ou numa total descrença da sua capacidade de ação efetiva, levando a que cada cidadão busque proteção para si mesmo.

Para as autoras a grande dificuldade de analisar a violência urbana em sentido mais amplo é o predomínio de leituras parciais, em encontrar respostas de curto prazo, 
simplistas e mágicas. Com isso, (STEINBERGER E CARDOSO, 2005, p. 89), propõem fazer uma leitura sobre esse fenômeno em termos Geopolíticos, isso equivale, segundo as autoras, a trabalhar com atores/agentes que detêm poder e que agem sobre o território onde a violência ocorre. Elas questionam o problema para que a violência não seja confundida com brutalidade, por isso citam um trecho da obra $A$ apologia da violência de Georges Sorel (CHEVALIER, 1998, p. 357, apud STEINBERGER E CARDOSO, 2005, p. 90):

\footnotetext{
"Violência deve distinguir-se cuidadosamente de força, como de brutalidade, deveria. [...] deveria reservar-se o termo força aos atos de autoridade, e o termo violência aos atos de revolta. Diríamos, pois, que a força tem por objeto impor a organização de uma certa ordem em que governa uma minoria, enquanto a violência tende à destruição dessa ordem. A burguesia tem empregado a força desde o início dos tempos modernos, enquanto o proletariado reage agora contra o Estado pela violência. Tal violência é inteiramente estranha aos atos de selvageria”.
}

Para isso, elas sugerem seguir alguns passos: o primeiro é mostrar que ator/agente, poder e território são elementos-chave para a compreensão da violência urbana; e que a primeira iniciativa, segundo as autoras é reconhecer que cada cidadão é ator responsável pela violência urbana, seja por ação ou omissão, seja por alienação ou por preconceito; a outra iniciativa seria reconhecer que a violência urbana envolve poder, representado por diferentes signos (poder de ação, poder de coação, etc) e inerentes a todos os atores sociais, isso porque, de acordo com as autoras esse poder, que é plural, pode ser transferido da violência para a não-violência; e por último, o reconhecimento de que a violência nas/das cidades, não tem uma territorialidade única e restrita a um urbano genérico, mas que existem territorialidades que são exercidas no território da casa e estendem-se à rua e ao bairro, à empresa, à escola, à igreja e ao clube. Para as autoras, urbana é tão-somente a territorialidade-síntese de manifestação 
e geração de violência. O segundo passo, de acordo com as autoras, é identificar os principais agentes que estão por trás dos atores da violência urbana. $\mathrm{O}$ terceiro e último passo é definir a quem cabe promover essa integração, ou seja, ao Estado o papel de coordenador dos agentes a um futuro.

2.2.1.1 - Os atores ou agentes, o poder e o território

Para (STEINBERGER E CARDOSO, 2005, p. 89), a discussão sobre a violência, ao contrário do que se pensa, não é um tema atual. Esteve presente na reflexão filosófica em todos os tempos. Desde Platão, Santo Tomás de Aquino, Nicolau Maquiavel, Thomas Hobbes, Kant, Hegel, Karl Marx, Engels e Weber; assim como em Sorel, Freud e Sartre, etc, (CABRAL, 1989 apud STEINBERGER E CARDOSO, 2005, p. 90).

Sobre o debate em torno do fenômeno violência, essas autoras constataram que, em relação aos três elementos-chave (atores/agentes, poder e território), houve muito mais ausência deles do que presença. As autoras citam, por exemplo, as idéias de Zaluar (apud STEINBERGER E CARDOSO, 2005, p. 87), no qual afirma que a violência está em toda parte, mas que não foi incluído os atores sociais permanentes reconhecíveis, nem causas facilmente delimitáveis e inteligíveis. Elas também citam as idéias de Waiselfisz (2004), em que esse autor afirma que as diversas formas de violência estão longe de serem produtos aleatórios de atores isolados, e sim, configuram tendências que encontram sua explicação nas situações sociais, políticas e econômicas que o Brasil atravessa. Outra idéia seria a de que: 
"Há violência quando, em uma situação de interação, um ou vários atores agem de maneira direta ou indireta, maciça ou esparsa, causando danos a uma ou mais pessoas em graus variáveis, seja em sua integridade física, seja em sua integridade moral, em suas posses, ou em suas participações simbólicas e culturais" (MICHAUD, 1989, p.10, apud STEINBERGER e CARDOSO, 2005, p.92).

Sobre o Poder, as autoras citam as idéias de Bourdieu apud (STEINBERGER E CARDOSO, 2005, p. 87), que propõe a "ordem do simbólico", no qual sugere que não se pode estabelecer uma separação entre o Poder e a Violência, pois os instrumentos simbólicos (língua, mito arte, etc) se exprimem por meio do poder e da violência, como instrumentos de dominação. Já o conceito de território, segundo as autoras, não é encontrado como expressão de poder, apropriação, pertencimento, mas como unidade geográfica de análise da violência externada pelo subdesenvolvimento territorializado, ou seja, o território é visto como mero receptáculo ${ }^{4}$. As autoras reforçam a idéia de que seria importante a busca do conceito de violência a partir de uma leitura da Geopolítica e não somente possuir uma constante preocupação em diagnosticar suas causas. Por isso, as autoras criticam a pouca atenção aos três elementos-chave (poder, atores/agentes e território), que segundo elas, estão muito presentes no espaço, principalmente no urbano.

Em relação aos elementos-chave: atores ou agentes, poder e território para explicar a violência, principalmente à violência urbana. As autoras afirmam que os atores é toda a sociedade responsável pela violência urbana, seja por ação ou por omissão, seja por alienação ou por preconceito. Isso porque a violência é um sintoma de que não somente alguns membros, mas toda a sociedade está doente (STEINBERGER E CARDOSO, 2005, p. 88). Para combater a violência, as autoras, afirmam que requer novas atitudes voltadas para a cidadania.

O poder, que é representado por diferentes signos e inerentes a todos os atores sociais. Esse poder é plural e pode ser transferido da violência para a não-violência, ou seja, o poder seria então a ação de mudança da sociedade. O território, que é múltiplo,

\footnotetext{
${ }^{4}$ - O território como receptáculo somente tem a função neutro perante as ações do homem;
} 
como o território da casa e estende-se à rua e ao bairro, mas também à empresa, à escola, à igreja e ao clube. Sobre os agentes, as autoras afirmam que os principais agentes, que estão por trás dos atores da violência urbana, são a família, a igreja, a escola e a empresa, além da polícia. São agentes capazes de aglutinar atores e por meio do poder modificar o território (STEINBERGER E CARDOSO, 2005, p. 89).

Ao analisar a violência nas escolas, deve-se observar que as idéias apresentadas por (STEINBERGER e CARDOSO, 2005), sobre a questão dos elementos-chave, que os atores/agentes, o poder e o território. A violência nas escolas possui atores ou agentes que estão envolvidos nessa dinâmica, que são os alunos, os diretores, os professores, etc. O poder que esses agentes exercem no interior da escola é primordial para dinamizar o ambiente escolar. E o território, que pode ser o espaço da própria escola, ou nas áreas de sua influência. Deve-se considerar que, segundo as autoras, para entender a violência, deve entender a dinâmica desses elementos.

\section{3 - A violência nas escolas}

Sobre as pesquisas feitas no Brasil, após 1980, (SPOSITO, 2001 apud CUBAS, 2006, p. 33) fez um levantamento que permitiu dividi-las em dois grupos distintos: o primeiro grupo de pesquisas realizadas majoritariamente por órgãos públicos da área da educação, associações locais ou gerais apresentando informações relevantes sobre o fenômeno, a pesar de não permitirem extrair um quadro preciso da situação da violência nas escolas. Segundo a autora que tais pesquisas não apresentam um quadro teórico interpretativo da violência na escola, apenas indícios que servem como base para pensar o fenômeno. O outro grupo inclui estudos de pós-graduação e de equipe de pesquisadores vinculados às universidades (SPOSITO, 2001 apud CUBAS, 2006, p. $33)$. 
Somente no início da década de 1980 é que o tema a violência nas escolas entra em voga no debate público no Brasil. Num momento de grande demanda por segurança, por parte dos moradores das periferias das grandes cidades, é que o fenômeno da violência nas escolas passa a ter visibilidades e, em grande parte, a partir de denúncias feitas sobre as condições precárias dos estabelecimentos escolares nessas regiões. Esse período é marcado pela percepção da violência a partir das depredações das instalações e da invasão do espaço escolar por pessoas sem vínculo com a instituição. Segundo a autora, predominava, nessa fase, a idéia de que a escola precisava ser protegida de elementos estranhos, daí a adoção de esquemas de proteção ao patrimônio.

Em relação às pesquisas nesse período, ocorre um maior interesse em registrar as ocorrências de violência nas escolas para a compreensão do fenômeno. Devido a não sistematização dos dados ou da recusa de algumas escolas em fornecer informações que dariam a ela uma imagem negativa, pois trata de um material informativo bastante irregular e precário.

Final dos anos 80 e início dos anos 90, em virtude da intensificação do crime organizado e do tráfico de drogas, há um recrudescimento do sentimento de insegurança na população em geral e, paralelamente a isso, a imprensa passa a dar destaque aos casos de homicídios. Por consequiência, o final dos anos 90 é marcado pelas iniciativas públicas, algumas em parceria com ONGs e a sociedade civil, que visavam à redução da violência. A partir delas busca-se desenvolver novas concepções sobre segurança, com ênfase no debate sobre a democratização dos estabelecimentos escolares (SPOSITO, 2001 apud CUBAS, 2006, p. 34).

Ao longo da década de 90, diversas entidades, ONGs, órgãos governamentais realizaram pesquisas e diagnósticos, nesse período destacam-se os surveys, realizados em vários capitais do país com o objetivo de identificar a relação entre jovens e violência nas escolas públicas. A partir dessas pesquisas e diagnósticos foi possível perceber algumas mudanças no padrão da violência em relação ao período anterior. O vandalismo continua a ocorrer, no entanto passa a ser registradas também agressões interpessoais entre os alunos, entre as quais as agressões verbais. As ameaças aparecem mais freqüentes, inclusive em cidades de porte médio. Nesse período, ainda 
de forma modesta, são iniciadas pesquisas de vitimização no ambiente escolar. As pesquisas desenvolvidas pelas universidades, nesse período, também contribuem para a compreensão do fenômeno e algumas delas apontam a influência exercida pelo aumento da criminalidade e da insegurança na determinação do clima escolar (SPOSITO, 2001 apud CUBAS, 2006, p. 34).

2.3.1 - O sistema educacional no Brasil

O Censo Demográfico de 2000 registrou que cerca de 53.406.320 pessoas freqüentavam creche ou escola naquele ano e que elas estavam distribuídas de acordo com a TABELA 1 abaixo:

TABELA 1 - Quantidade de pessoas que freqüentavam creches ou escolas em 2000.

\begin{tabular}{|c|c|c|c|c|c|c|c|c|c|}
\hline \multicolumn{10}{|c|}{$\begin{array}{l}\text { PESSOAS QUE FREQUENTAVAM CRECHE OU ESCOLA, POR NÍVEL DE ENSIO, SEGUNDO A } \\
\text { REDE DE ENSINO }\end{array}$} \\
\hline \multirow{4}{*}{$\begin{array}{c}\begin{array}{c}\text { Rede } \\
\text { de }\end{array} \\
\text { ensino, } \\
\text { sexo e } \\
\text { grupos } \\
\text { de } \\
\text { idade } \\
\end{array}$} & \multicolumn{9}{|c|}{ Pessoas que freqüentavam creche e escola } \\
\hline & \multirow[b]{3}{*}{ Total } & \multicolumn{8}{|c|}{ Nível de ensino } \\
\hline & & \multicolumn{2}{|c|}{ Educação infantil } & \multirow[b]{2}{*}{$\begin{array}{l}\text { Alfabeti- } \\
\text { zação de } \\
\text { adultos }\end{array}$} & \multirow[b]{2}{*}{$\begin{array}{c}\begin{array}{c}\text { Fundame- } \\
\text { ntal }\end{array} \\
\end{array}$} & \multirow[b]{2}{*}{ Médio } & \multirow[b]{2}{*}{$\begin{array}{c}\text { Pré- } \\
\text { vestibular }\end{array}$} & \multicolumn{2}{|c|}{ Superior } \\
\hline & & Creche & $\begin{array}{l}\text { Pré- } \\
\text { escolar } \\
\text { (1) }\end{array}$ & & & & & $\begin{array}{l}\text { Gradua- } \\
\text { ção }\end{array}$ & $\begin{array}{c}\text { Mestrado } \\
\text { ou } \\
\text { Doutorado }\end{array}$ \\
\hline Total & 53.406 .320 & 1.114.271 & 6.176.926 & 459.891 & 33.886.031 & 8.302.599 & 440.046 & 2.864.046 & 162.512 \\
\hline \multicolumn{10}{|c|}{ Rede de Ensino } \\
\hline $\begin{array}{l}\text { Particu- } \\
\text { Lar }\end{array}$ & 10.068 .149 & 368.337 & 1.954 .110 & 24.592 & 3.712 .046 & 1.529 .814 & 39.138 & 2.011 .140 & 76.671 \\
\hline $\begin{array}{l}\text { Públi- } \\
\text { Ca }\end{array}$ & 43.338.172 & 745.934 & 4.222 .816 & 435.298 & 30.173 .985 & 6.772 .785 & 48.508 & 853.006 & 85.840 \\
\hline
\end{tabular}

Fonte: IBGE - Censo Demográfico, 2000.

(1) Inclusive as pessoas que freqüentavam classe de alfabetização. 
Das pessoas que freqüentavam creche ou escola naquele período, corresponderia a um percentual de $31,5 \%$ do total da população brasileira naquele ano. Desse total de estudantes, $13,7 \%$ corresponderia aos que freqüentavam a Educação Infantil; $0,9 \%$ eram adultos que estavam sendo alfabetizados; 63,4\% estavam no Ensino Fundamental, que corresponde ao maior percentual; 15,5\% estavam no Ensino Médio e cerca de $0,8 \%$ freqüentavam o Pré-vestibular. Quanto o Nível Superior, seu percentual de estudantes era de $5,7 \%$, que quando dividido entre a graduação e o mestrado/doutorado, corresponderia a $5,4 \%$ e $0,3 \%$, respectivamente.

Quanto a rede de ensino, do total de 53.406 .320 pessoas que freqüentavam creche ou escola, cerca de $81 \%$ estavam matriculados na Rede Pública de Ensino, ou seja, quando se analisa a distribuição dos estudantes nos níveis, a rede pública de ensino concentra a maioria dos estudantes no Ensino Básico. Já no Ensino Superior, a concentração se inverte, a maioria dos estudantes desse ensino, cerca de 69\%, estavam matriculados na Rede Particular de Ensino.

\subsection{2 - A definição da violência nas escolas}

\footnotetext{
"Definir a violência na escola é, antes, mostrar como ela é socialmente construída em sua própria designação, como seu campo semântico se amplia a ponto de se tornar uma representação social central" (DEBARDIEUX, 2001, p. 164 apud PAREDES, 2006, p. 16).
}

Quando se faz uso do termo "violência", que é tão amplo e que abrange desde agressões graves até as pequenas incivilidades que acontecem na escola. Mas o grande problema na definição de violência são os inúmeros tipos de situações envolvidas ou pode, simplesmente, passar a criminalizar e estigmatizar padrões de comportamento 
comuns no ambiente escolar. Ou então, ao mesmo tempo, ao adotar uma definição excessivamente limitada, que pode acabar excluindo a experiência de algumas vítimas no processo de reflexão sobre o problema. "A voz das vítimas deve ser levada em consideração na definição de violência, que diz respeito tanto a incidentes múltiplos e causadores de stress, que acabam à punição, quanto à agressão brutal e caótica" (DEBARBIEUX, 2002 apud CUBAS, 2006, p. 41).

O problema da violência escolar não é um fenômeno recente, mas o que pode ser considerado novo são as formas pelas quais a violência se manifesta, por isso (CHARLOT, 2002, p. 40 apud CUBAS, 2006, p. 45), divide em quatro aspectos: primeiro, o surgimento de formas de violência mais graves, mesmo raras; em segundo é a questão da idade ser cada vez menor dos alunos envolvidos nos casos de violência; a outra é a ação de agentes externos que ocupam o espaço da escola com agressões geradas fora dela; por último, seria a repetição e o acúmulo de pequenos casos que não são necessariamente violentos, mas que criam a sensação de ameaça permanente.

A forte influência da mídia sobre os pesquisadores (DEBARBIEUX, 2002 apud CUBAS, 2006, p. 46), é um ponto que deve ser considerado. Isso porque acaba conduzindo as pesquisas acadêmicas a uma "pré-fabricação social da violência nas escolas", ou seja, os especialistas que ainda têm pouca informação a respeito do fenômeno acabam, em alguns casos, endossando o que lhes é apresentado, e muitas vezes de forma exacerbada, pela mídia.

$\mathrm{Na}$ contemporaneidade os especialistas têm privilegiado a análise da violência entre alunos ou a violência desses para a escola e, em menores proporções, a violência que ocorre entre os alunos e professores. Há também a questão, no qual é freqüente o esforço dos pesquisadores em tentar encontrar uma definição, o mais abrangente possível, para os diferentes tipos de violência que ocorrem nas escolas. O grande problema é que as especificidades dos trabalhos realizados com abordagens diferenciados acabam enfatizando alguns aspectos em detrimento de outras, exigindo que cada um construa a sua definição de violência mais adequada (ABRAMOVAY, 2002 apud CUBAS, 2006, p. 47).

O fato de haver muitas dificuldades em definir violências, (CUBAS, 2006, p. 48), afirma que muitos autores alertam que a constante presença da violência no 
ambiente escolar coloca em xeque a função primordial da escola. Assim, de instituição encarregada de socializar as novas gerações, a escola passa a ser vista como um ambiente que concentra conflitos e práticas de violências. Por isso, o principal papel dos estudos e pesquisas é demonstrar que a violência que acontece não é casual, é socialmente construída e, por isso mesmo, pode ser previsível. A partir do momento em que se tem o conhecimento sobre a origem da violência que está presente em nossas escolas é possível elaborar estratégias de ação que impeçam que ela continue e se desenvolva (CUBAS, 2006, p. 48).

\footnotetext{
"A definição da violência escolar possui dificuldades porque ela remete aos fenômenos heterogêneos, difícios de delimitar e de ordenar e também porque desestrutura as representações sociais que têm valor fundador, como por exemplo, aquela da infância, como algo inocente, como a escola, que é refúgio de paz; e da própria sociedade, vista com pacífica no regime democrática” (CHARLOT, 1997 apud ABRAMOVAY; RUA, 2002, p. 69).
}

\subsection{3 - A violência no cotidiano da escola}

Outra tarefa complexa é identificar, na prática, quais os atos devem ser considerados violentos e como podem ser evitados. Primeiro, a violência no cotidiano das escolas associar-se-ia, segundo (DEBARBIEUX, 1999 apud ABRAMOVAY, 2003, p. 78), a três dimensões sócio-organizacionais distintas: 
- Em primeiro lugar, à degradação no ambiente escolar, isto é, à grande dificuldade de gestão das escolas, resultando em desestruturas deficientes;

- Em segundo, a uma violência que se origina de fora para dentro das escolas, que as torna "sitiadas" e se manifesta por intermédio da penetração das gangues, do tráfico de drogas e da visibilidade crescente da exclusão social na comunidade escolar;

- Em terceiro, relaciona-se a um componente interno das escolas, específico de cada estabelecimento, ou seja, existem escolas historicamente que têm se mostrada violentas, outras passam por situações de violência, assim como pode se observar a existência de escolas seguras em bairros violentos ou vice-versa, sugerindo que não existe determinismo nem fatalidades.

Autores como (CHARLOT, 2002 apud CUBAS, 2006, p. 49) apresenta três tipos diferentes de manifestação na escola. São elas: a violência na escola, ou seja, quando o local escolar é invadido por questões externas a ela, por exemplo, quando um grupo invade a escola para brigar com alguém que está no interior dela. Essa manifestação de violência na escola, segundo a autora, está relacionado às questões que acontecem fora da escola, como por exemplo, situações corriqueiras de violência que acontecem nos grandes centros urbanos, como as brigas das gangues, nas quais essas invadem o ambiente escolar, onde pode estar membros de gangues rivais, para acerto de contas, por causa da disputa de domínios das regiões dominadas por essas gangues. A violência à escola, que está relacionada às atividades institucionais e que diz respeito a casos de violência direta contra a instituição, como por exemplo, a depredação do patrimônio, ou então, casos de violência contra aqueles que representam a instituição, como os professores. Esse tipo de violência contra à escola é muito comum, isso porque o número de escolas públicas completamente depredadas nas regiões urbanas é alto. A terceira é a violência da escola, que é entendida como a violência onde as vítimas são os próprios alunos, que pode ser exemplificada no tipo de relacionamento estabelecido entre professores e alunos, ou então, a partir de 
métodos de avaliação e de atribuição de notas que refletem preconceitos e estigmas, ou seja, outros critérios que não os objetivos de desempenho.

Outros autores tentam estabelecer uma hierarquia entre as diversas concepções de violência a partir do custo social de cada uma delas. Essa hierarquia seria a seguinte: primeiro, a violência física que compreende os episódios em que há danos à vida dos indivíduos; em segundo, a violência econômica que se refere a danos causados ao patrimônio; terceiro, a violência moral ou simbólica.

Já outros trabalhos como de (ABRAMOVAY, 2002 apud CUBAS, 2006, p. 49) faz uma classificação mais simples das causas da violência na escola. As variáveis seriam externas e internas à escola, que são: as causas externas, que envolve os ideais de gênero como os conflitos entre os sexos; as relações raciais, como o racismo, a xenofobia, a migração e até os conflitos regionais; a estrutura familiar dos alunos também influencia e muito; a influência da mídia; as características do ambiente onde a escola está inserida. As causas internas à escola, se originam no interior da escola, que podem ser enumerados como a idade e o nível de escolaridade dos alunos; as regras, as disciplinas e o sistema de punições das escolas; a indiferença dos professores frente a todos os casos de violência, a má qualidade do ensino, carência de recursos humanos e a relação de autoridade entre professores e alunos.

$\mathrm{Na}$ conceitualização geral da violência escolar, (CHARLOT, 1997 apud ABRAMOVAY, 2006, p. 62), classifica a violência escolar em três níveis:

I. A violência - golpes, ferimentos, violência sexual, roubos, crimes, vandalismos;

II. Incivilidades - humilhações, palavras grosseiras, falta de respeito;

III. Violência simbólica ou institucional - falta de sentido em permanecer na escola por tantos anos; o ensino como um desprazer, que obriga o jovem a aprender matérias e conteúdos alheios aos seus interesses; as imposições de uma sociedade que não sabe acolher os seus jovens no mercado de trabalho; a violência das relações de poder entre professor e alunos; a negação da identidade e satisfação profissional aos professores, a sua obrigação de suportar o absenteísmo e a indiferença dos alunos. 
"Como a falta de sentido de permanecer na escola por tantos anos, o ensino como um desprazer, que obriga o jovem a aprender matérias e conteúdos alheios aos seus interesses; as imposições de uma sociedade que não sabe acolher os seus jovens no mercado de trabalho; a violência das relações de poder entre professores e alunos. Também o é a negação da identidade e satisfação profissional aos professores, a sua obrigação de suportar o absenteísmo e a indiferença dos alunos" (CHARLOT, 1997 apud ABRAMOVAY; RUA, 2002, p. 69).

Uma outra forma de violência muito comum nas escolas é o Bullying, que é freqüentemente usado para descrever uma forma de assédio interpretado por alguém que está, de alguma forma, em condições de exercer o seu poder sobre alguém ou sobre um grupo mais fraco. O bullying entra como uma incivilidade na classificação de Charlot (1997). O cientista sueco, Dan Olweus, define bullying em três termos essenciais: primeiro, o comportamento é agressivo e negativo; o segundo é que ele é executado repetidamente; outro termo é que o comportamento ocorre num relacionamento onde há um desequilíbrio de poder entre as partes envolvidas.

O bullying divide-se em duas categorias:

I. bullying direto;

II. bullying indireto, também conhecido como agressão social

O bullying direto é a forma mais comum entre os agressores (bullies) masculinos. A agressão social ou bullying indireto é a forma mais comum em bullies do sexo feminino e crianças pequenas, e é caracterizada por forçar a vítima ao isolamento social. Este isolamento é obtido através de uma vasta variedade de técnicas, que incluem: 
- espalhar comentários;

- recusa em se socializar com a vítima

- intimidar outras pessoas que desejam se socializar com a vítima

- criticar o modo de vestir ou outros aspectos socialmente significativos (incluindo a etnia da vítima, religião, incapacidades etc).

O bullying pode ocorrer em situações envolvendo a escola ou faculdade/universidade, o local de trabalho, os vizinhos e até mesmo países. Qualquer que seja a situação, a estrutura de poder é típicamente evidente entre o agressor (bully) e a vítima. Para aqueles fora do relacionamento, parece que o poder do agressor depende somente da percepção da vítima, que parece estar a mais intimidada para oferecer alguma resistência. Todavia, a vítima geralmente tem motivos para temer o agressor, devido às ameaças ou concretizações de violência física/sexual, ou perda dos meios de subsistência.

Mesmo que os autores utilizem diferentes formas de abordagem do fenômeno violência nas escolas, o fato é que o problema existe e que está presente a cada dia na escola, nos mais diferentes países, classe social e que se manifesta sob os múltiplos aspectos. Nos EUA o fenômeno é chamado de bullying, enquanto na França de incivilidades, (CUBAS, 2006, p. 170), mas ambos estão se referindo a um mesmo problema, ou seja, ambos tratam da violência explícita o implícita que ocorre na escola e que impede a construção de relações harmoniosas, favorecendo o sentimento de medo e exclusão no ambiente escolar. No Brasil, o estudo sobre a violência nas escolas é mais recente do que nos países citados anteriormente, (CUBAS, 2006, p. 171), por isso ocorrem intensos debates em torno do problema e a procura de soluções, principalmente nas escolas públicas do Brasil. 
2.4 - A violência nas escolas públicas do Distrito Federal

No Distrito Federal $32,6 \%$ da população são estudantes, que são divididos no Ensino Básico, Superior, Profissionalizante e na Educação de Jovens e Adultos. Quando se analisa o gráfico, observa-se que percentual de estudantes nas RAs é praticamente homogêneo. Tendo a RA do Cruzeiro com o maior percentual, com $38,1 \%$, logo em seguida vem o Paranoá, com 37,5\%. Os menores índices são o Varjão e o Itapoã, com $25,4 \%$ e $26,5 \%$, respectivamente. O gráfico abaixo mostra o percentual de estudantes nas RAs em 2004. 


\section{GRÁFICO 1 - Distribuição Espacial dos Estudantes no Distrito Federal}

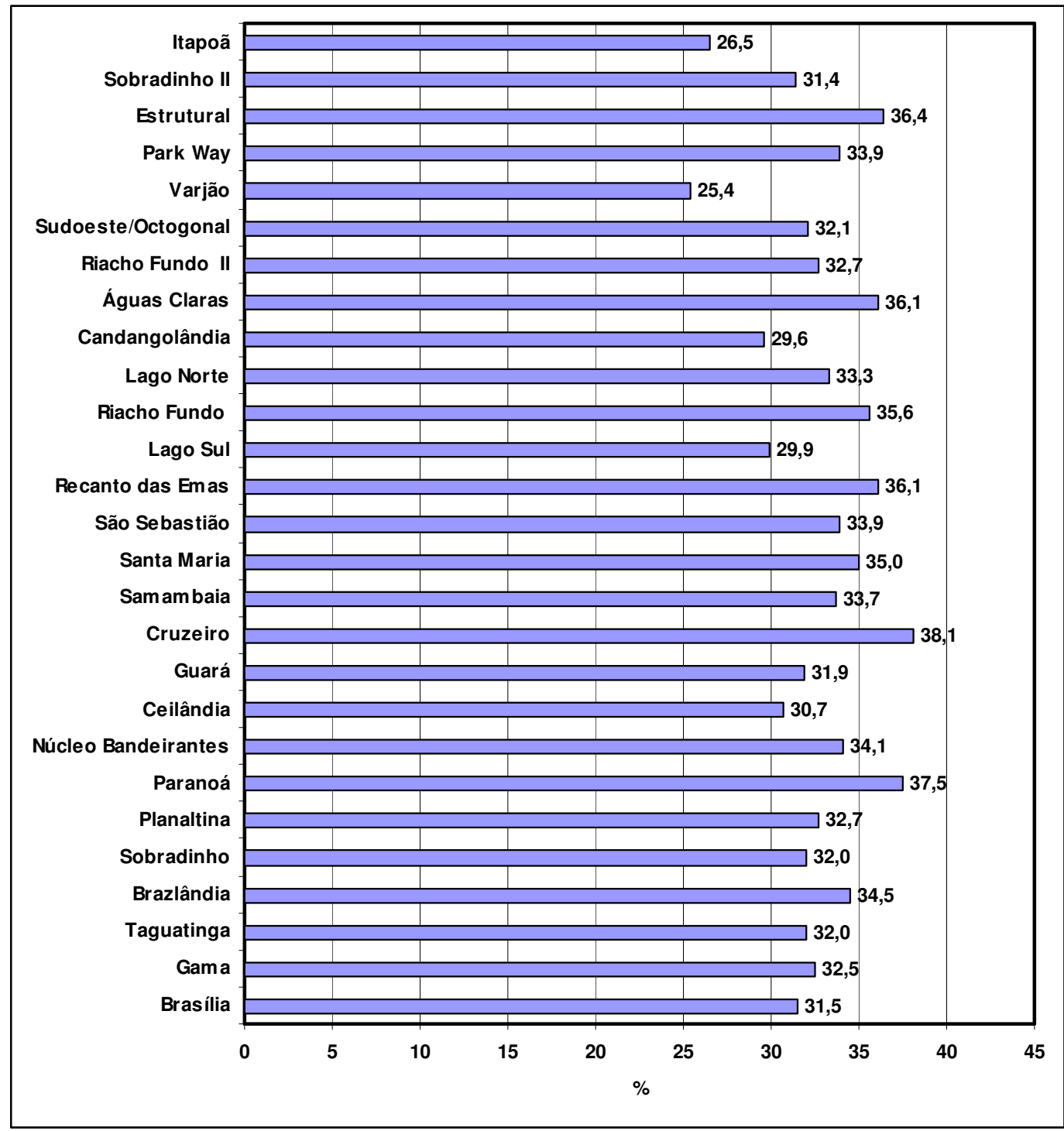

Fonte: SEPLAN/CODEPLAN - Pesquisa Distrital por Amostra de Domicílios - PDAD, 2004.

(1) Para a Região Administrativa XXVII - Jardim Botânico não existem informações por ter sido criada após o término da pesquisa.

(2) A Região Administrativa XXIX - SIA foi criada em 2005 e não possui unidades residenciais.

A Secretaria de Educação do Distrito Federal (SEDF) em parceria com a Rede de Informação Tecnológica Latino-Americana (Ritla) realizaram uma pesquisa nas escolas públicas do Distrito Federal sobre a violência. Seus resultados vão subsidiar, 
segundo a SEDF, um Plano de Convivência Escolar que será implantado na rede pública de ensino.

Conforme os órgãos, o estudo adotou técnicas quantitativas e qualitativas de pesquisa para possibilitar uma visão mais completa do fenômeno da violência nas instituições de ensino da rede pública do DF.

A pesquisa foi realizada entre junho e setembro de 2008, no qual foram aplicados 9.937 questionários para os alunos da $5^{\mathrm{a}}$ série do Ensino Fundamental a $3^{\mathrm{a}}$ série do Ensino Médio, 1.330 questionários a professores, tendo um total de 11.267 entrevistados (ver TABELA 2).

TABELA 2

\begin{tabular}{|l|c|}
\hline \multicolumn{2}{|c|}{ Dados dos Entrevistados } \\
\hline Alunos & 9.937 \\
\hline Professores & 1.330 \\
\hline Total & $\mathbf{1 1 . 2 6 7}$ \\
\hline
\end{tabular}

Fonte: SEDF/Ritla, 2008

O levantamento foi realizado em 84 escolas distribuídas nas 14 Diretorias Regionais de Ensino (DREs), sendo 6 instituições educacionais, que foi dividido em 4 de ensino fundamental e 2 de ensino médio, por DRE.

O secretário de educação do Distrito Federal, José Luiz da Silva Valente, explica que esse diagnóstico tem como objetivo principal fornecer dados e informações para subsidiar o desenvolvimento de políticas e ações voltadas para o enfrentamento da violência nas escolas públicas do DF. Ele afirma:

"A violência é um fenômeno social complexo, que está em todo lugar, mas que assume contornos específicos no ambiente escolar. Por isso é fundamental utilizar todos os tipos de instrumentos disponíveis para conhecê-lo e compreendêlo" (SILVA VALENTE, JOSÉ LUIZ DA. SECRETÁRIO DE ESTADO DE EDUCAÇÃO DO DF) 
Valente enfatiza que a violência nas escolas não é um problema exclusivo do Distrito Federal, manifestando-se, muitas de modo intenso, em outras partes do Brasil e, até, outros países. Apesar disso, continua o secretário, a intenção da SEDF é conhecer o que está ocorrendo de fato nas escolas para que seja tomada as medida adequadas.

2.4.1 - Os tipos de violência encontrados nas entrevistas

De acordo com os órgãos foi investigada, de um lado, a percepção de alunos e professores sobre a existência de violência nas escolas e, de outro, se elas foram vítimas ou agentes de atos que envolvem violência. A Secretaria de Educação classificou os atos de violência em 5 classes e subdividiu-as em tipos de violência que mais acontecem nas escolas. As 5 classe de violência são:

- Cyberviolência;

- Microviolência;

- Violência Simbólica;

- Violência "dura";

- Violência Sexual.

De acordo com a SEDF, na Cyberviolência envolve as ações de violência psicológica por uma pessoa ou grupo contra uma terceira pessoa com o uso de meios eletrônicos, principalmente a Internet. Os tipos de violência mais comum dessa classe são as ameaças, a invasão de e-mails, os xingamentos e fazer-se passar por outra pessoa, segundo a pesquisa. 
Já na Microviolência, que envolveria as relações interpessoais do dia a dia, a vivência em comunidades, segundo a pesquisa, as ações de violência mais comum são os xingamentos ou agressões verbais, ofensas ás famílias. Enquanto na Violência Simbólica, envolve a discriminação ou os preconceitos que ocorrem dentro das escolas, que no caso, as mais comuns são a discriminação por causa da cor ou raça, a discriminação por causa da orientação sexual e o preconceito por causa da condição social ou econômica.

Na Violência “dura”, que é um tipo de violência relacionada ao patrimônio da escola, dano físico entre as pessoas, que no caso, as ações mais comuns são as ameaças, as agressões físicas, os roubos ou furtos, as ações de gangues, o comércio ou tráfico de drogas e principalmente a pichação ou depredação da escola.

Por último, a questão da Violência Sexual, que envolve os atos relacionados aos abusos ou tentativas, que são: tentar beijar ou beijaram alguém à força, tocar ou tentaram tocar alguém de modo sexual à força, tirar ou tentaram tirar as roupas de alguém à força e forçar ou forçaram relações sexuais com alguém.

Considerando os efeitos e impactos da violência no ambiente escolar, o secretário de Educação do Distrito Federal, José Luiz da Silva Valente, reitera ser fundamental encarar essa questão de frente, por meio de políticas e ações que, numa frente, promovam a prevenção da violência nas escolas e, em outra, fortaleçam a capacidade das equipes escolares darem o encaminhamento devido às situações de violência instalada.

A psicóloga (ABRAMOVAY, 2006, p. 120) afirma que a violência é construída, logo, poder ser também desconstruída com estratégias que protejam as escolas da violência, tanto as que vêm de fora para dentro, como as interiores, aquelas que fazem parte do contexto escolar. Segundo a autora, não existem situações determinantes, e a origem da violência faz parte de um quadro institucional e social, que por sua vez, está sujeito a mudanças. 


\section{CAPÍTULO 2}

3.1 - Dados dos alunos pesquisados

A pesquisa foi feita no Centro Educacional 123 em Samambaia com alunos do Ensino Médio. Foi elaborado um questionário com 13 perguntas, no qual o objetivo seria avaliar a percepção dos alunos sobre a violência na escola. Foram listadas várias situações de violência e nas quais os alunos marcariam as opções de violência que eles sabem que acontece no ambiente escolar. $\mathrm{O}$ total de alunos pesquisados foi de 45 alunos, nos quais, foram divididos em três níveis: 15 alunos do $1^{\circ}$ Ano, 15 alunos do $2^{\circ}$ Ano e mais 15 do $3^{\circ}$ Ano. Todos os estudantes com idade que varia de 15 a 17 anos.

Sobre a distribuição por sexo, foram 22 jovens do sexo feminino e 23 do sexo masculino (ver TABELA 3).

TABELA 3

\begin{tabular}{|l|l|}
\hline \multicolumn{2}{|c|}{ Dados dos Estudantes } \\
\hline Feminino & 22 \\
\hline Masculino & 23 \\
\hline Total & 45 \\
\hline
\end{tabular}

Fonte: Pesquisa de Campo, 02/06/2009, Geilson dos Santos Sales 
3.2 - Os tipos de violência que ocorre no Centro Educacional 123 em Samambaia

De acordo com a pesquisa as violências mais comuns que acontecem e utilizando a classificação dada pela Secretaria de Educação do Distrito Federal SEDF, foram classificadas da seguinte forma:

\section{Microviolência;}

2. Violência Simbólica;

\section{Violência "dura";}

\section{Violência Sexual.}

Na Microviolência, que envolve relações interpessoais do dia a dia, os casos mais comuns, de acordo com a pesquisa, são: o xingamento ou a agressão verbal, as ofensas às famílias e as ameaças.

Enquanto na Violência Simbólica, que envolve a discriminação ou o preconceito, a pesquisa apontou que é comum na escola acontecer: a discriminação por causa da cor ou raça, por causa da orientação sexual, assim como a condição social. E em menor grau a discriminação por causa da região onde a pessoa mora e por causa da religião que a pessoa segue.

Na Violência “dura”, que é um tipo de violência relacionada ao patrimônio da escola e o dano físico entre as pessoas, os casos mais comuns, conforme a pesquisa, são: as ameaças, as agressões, os roubos ou furtos, o comércio ou tráfico de drogas e principalmente a pichação ou depredação da escola.

Por último, a Violência Sexual, que de acordo com a pesquisa é comum ver nas dependências da escola: a tentativa de beija ou beijaram alguém à força, tocar ou tentaram tocar alguém de modo sexual à força e forçar ou forçaram relações sexuais 
com alguém. A questão de forçar ou forçaram relações sexuais com alguém é apontado por um número muito pequeno de alunos.

3.3 - Resultados e análise das entrevistas

\subsection{1 - A Microviolência}

GRÁFICO 2: A percepção dos alunos sobre o comportamento da maioria dos colegas ${ }^{5}$

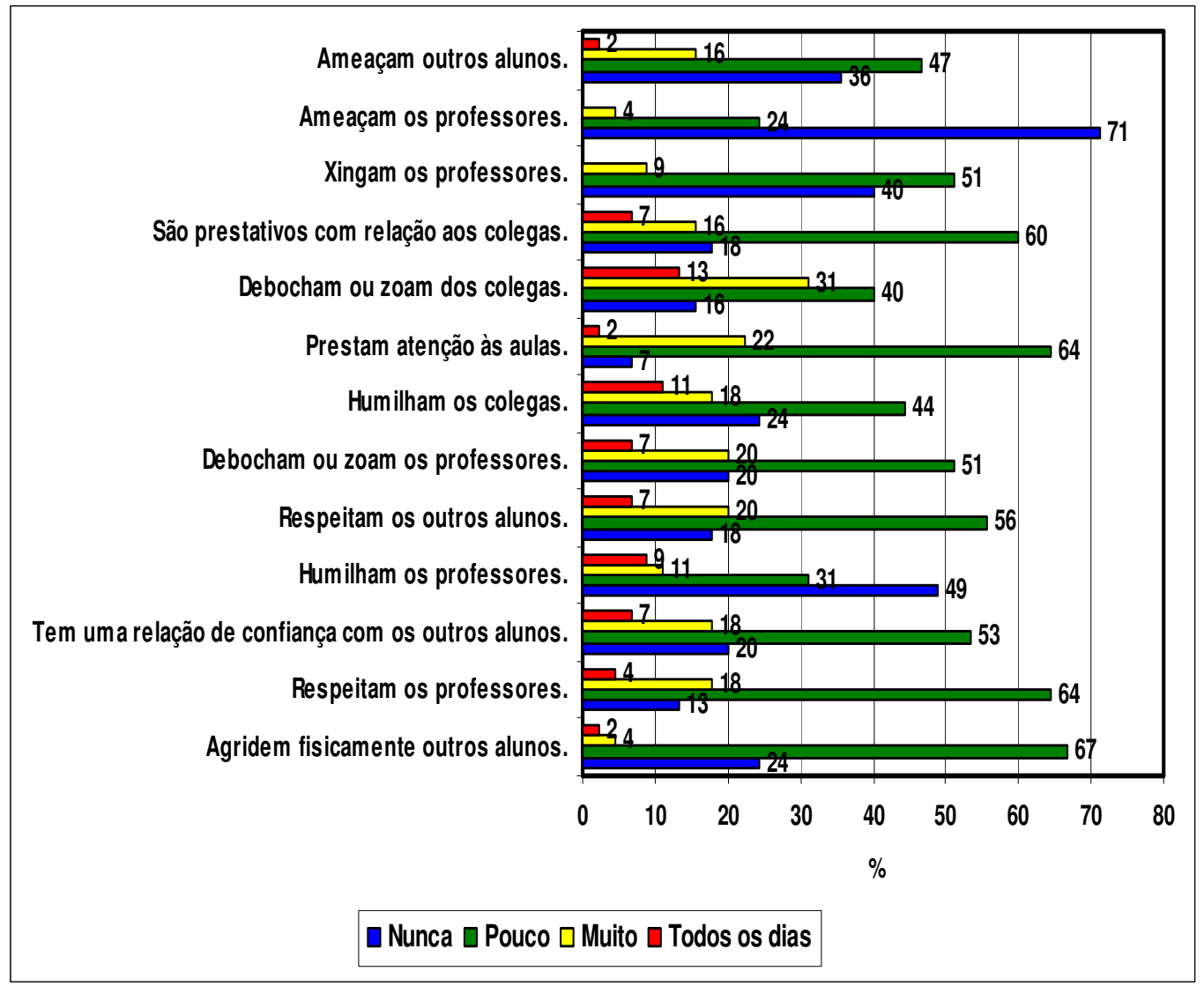

Fonte: Pesquisa de Campo, 02/06/2009, Geilson dos Santos Sales

\footnotetext{
${ }^{5}$ Nota: Foi perguntado aos alunos - Como você descreve o comportamento da maioria dos alunos de sua escola?
} 
Esse tipo de violência, que envolve as relações interpessoais, principalmente um tipo de violência muito comum nas escolas, o Bullying. De acordo com a percepção do comportamento da maioria dos alunos, em relação ao comportamento dos colegas, o que mais acontece na escola são o deboche ou zoar de outros colegas, no qual $13 \%$ dos alunos afirmam que acontece esse problema todos os dias. Cerca de $11 \%$ dos estudantes afirmam que a humilhação a colegas é corriqueira no ambiente escolar, ou seja, todos os dias. Um fato relevante no ambiente escolar é que $60 \%$ dos entrevistados afirmam que são pouco prestativos aos colegas e $64 \%$ dizem que poucos prestam atenção às aulas. Pode-se observar que uma total indiferença dos alunos em relação aos colegas e as aulas.

\section{GRÁFICO 3: A percepção dos alunos sobre o seu próprio comportamento ${ }^{6}$}

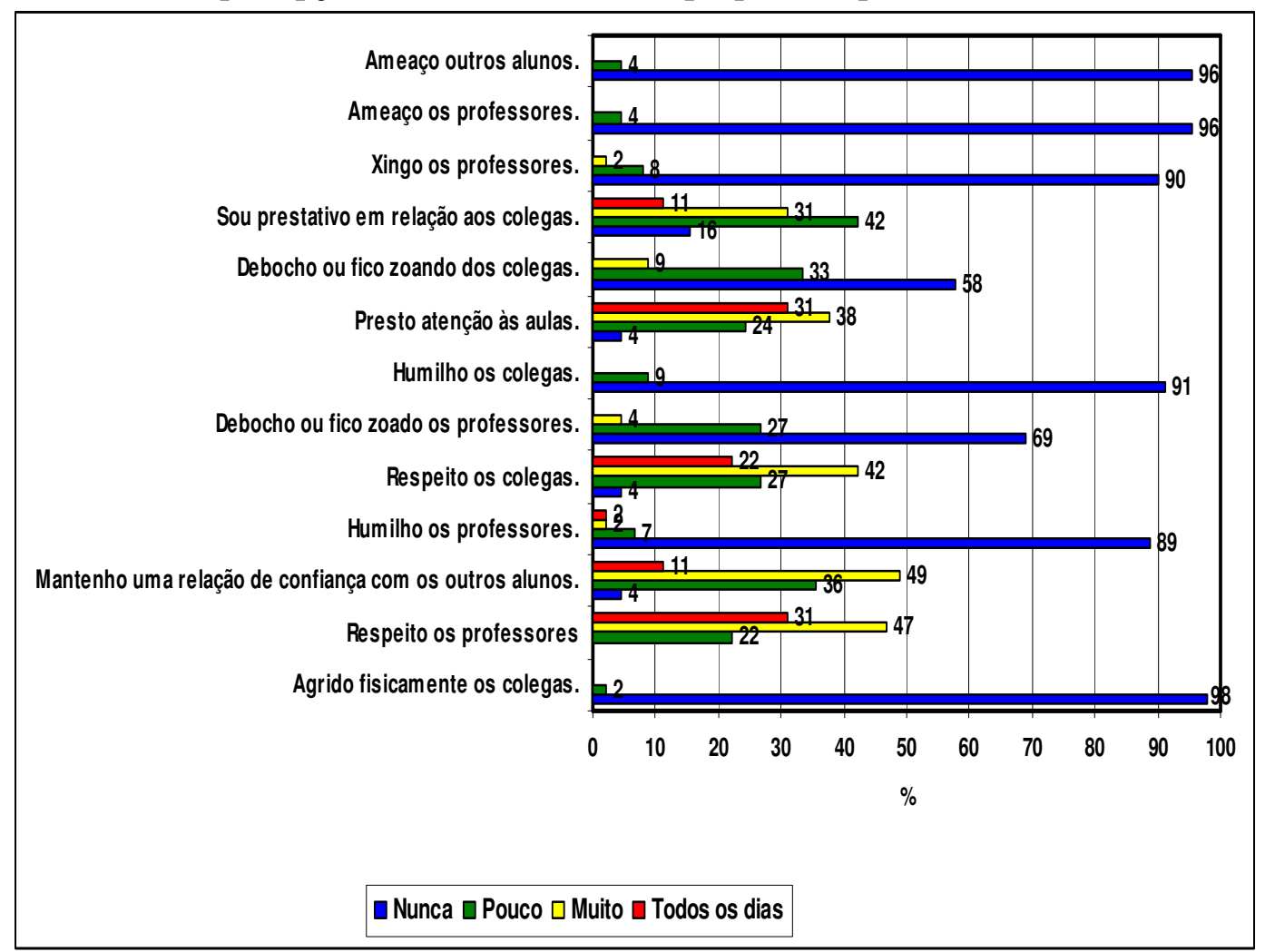

Fonte: Pesquisa de Campo, 02/06/2009, Geilson dos Santos Sales

\footnotetext{
${ }^{6}$ Nota: Foi perguntado aos alunos - Como você descreve o seu comportamento na escola?
} 
Sobre a percepção sobre o próprio comportamento, as relações que envolve o Bullying, como humilhações aos colegas, o deboche ou zoação a outros colegas acontecem Nunca ou Poucas vezes. O que aconteceu foi uma relação mais positiva, como ter uma relação de confiança com os outros alunos, o respeito aos professores e aos colegas. Para $98 \%$ dos entrevistados, nunca agrediu um colega da escola, enquanto $96 \%$ que nunca ameaçou um professor ou colega.

\subsection{2 - A Violência Simbólica}

GRÁfICO 4: Percentual de alunos que sabem que tipo de discriminação ou preconceito aconteceu na escola entre 2008 e $2009^{7}$

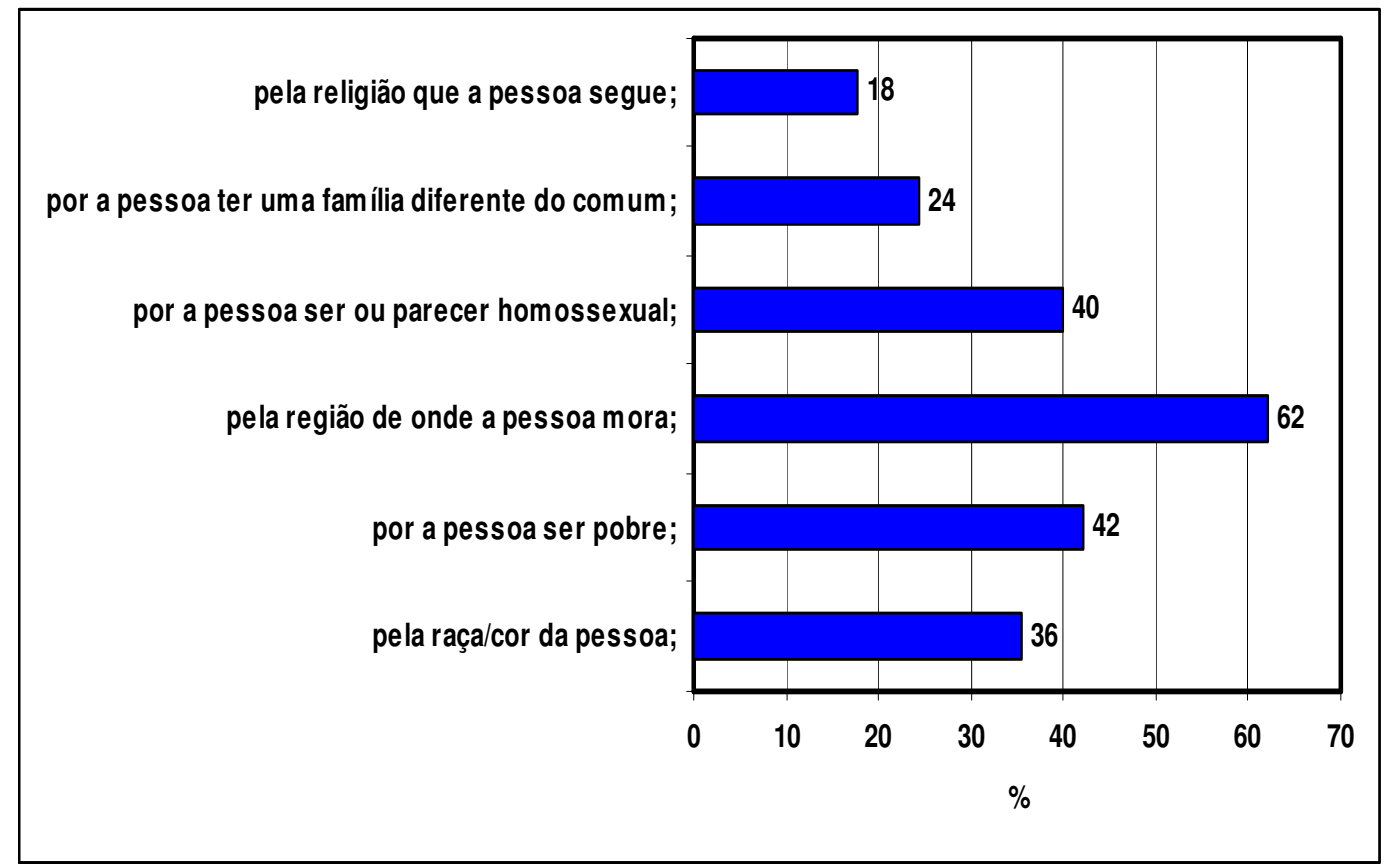

Fonte: Pesquisa de Campo, 02/06/2009, Geilson dos Santos Sales

\footnotetext{
${ }^{7}$ Nota: Foi perguntado aos alunos - Que tipo de preconceito ou discriminação você já viu acontecer na sua escola? (Você pode marcar mais de uma opção).
} 
Esse tipo de violência envolve a questão da discriminação ou preconceito entre as pessoas. As discriminações podem ocorrer de várias formas. Pela cor ou raça da pessoa, pela opção sexual, pelas condições financeiras da pessoa, etc. De acordo com a pesquisa, o tipo de discriminação mais comum que ocorre na dependência da escola é a Discriminação pela região de onde a pessoa mora, de acordo com $62 \%$ dos entrevistados, isso porque a Região Administrativa de Samambaia possui uma população de baixa renda e muitas regiões de pouca infra-estrutura, com isso, muitas famílias são obrigadas a morarem em áreas totalmente insalubres. Já $42 \%$ afirmam que ocorre Discriminação por a pessoa ser pobre e $40 \%$ afirmam que existe Discriminação por a pessoa ser ou parecer homossexual. Outro tipo de discriminação entre os estudantes é a questão da raça/cor, em que 36\% afirmam que acontece na escola. Enquanto a discriminação pela religião que a pessoa segue acontece em menor grau.

GRÁFICO 5: Percentual de alunos que sofreram preconceito ou discriminação na escola entre 2008 e $2009^{8}$

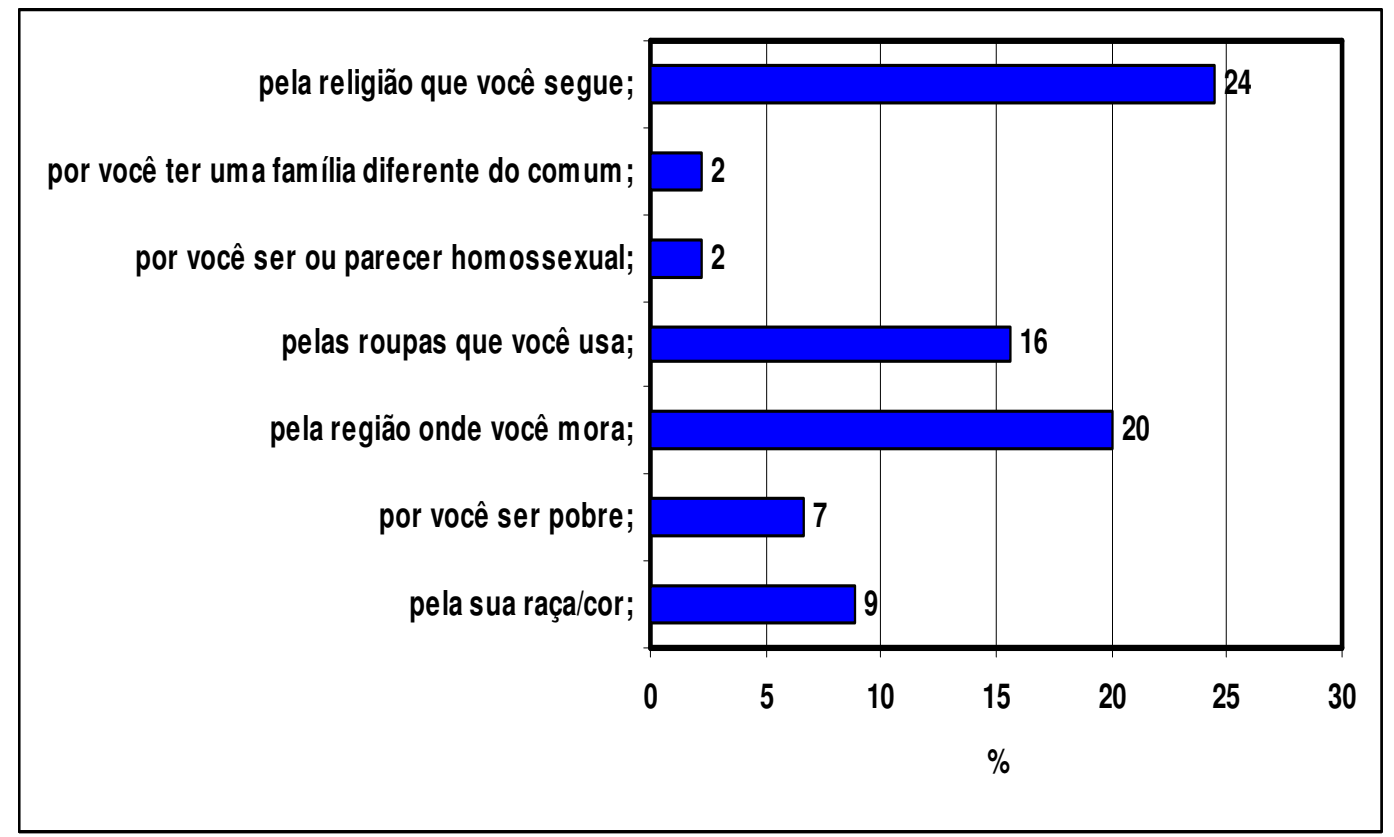

Fonte: Pesquisa de Campo, 02/06/2009, Geilson dos Santos Sales

\footnotetext{
${ }^{8}$ Nota: Foi perguntado aos alunos - Que tipo de preconceito ou discriminação você já sofreu na sua escola? ( marque mais de uma opção).
} 
Quanto aos alunos que já sofreram preconceito ou discriminação na escola, cerca de $20 \%$ afirmam que sofreram Discriminação pela região onde mora, seguida da Discriminação pela religião que segue, que corresponde por cerca de $24 \%$ dos estudantes. A discriminação por causa das roupas que usa também é muito comum ente os estudantes, no qual cerca de $16 \%$ dos alunos afirmam que sofreram esse tipo de preconceito ou discriminação. Enquanto a discriminação por você ser ou parecer homossexual ou por você ter uma família diferente do comum, acontece em menor grau, ou seja, apenas $2 \%$ afirmam ter recebido esse tipo de discriminação.

\subsection{3 - A Violência "dura"}

GRÁFICO 6: Percentual de alunos que sabem o que aconteceu atos de violência na escola entre 2008 e $2009^{9}$

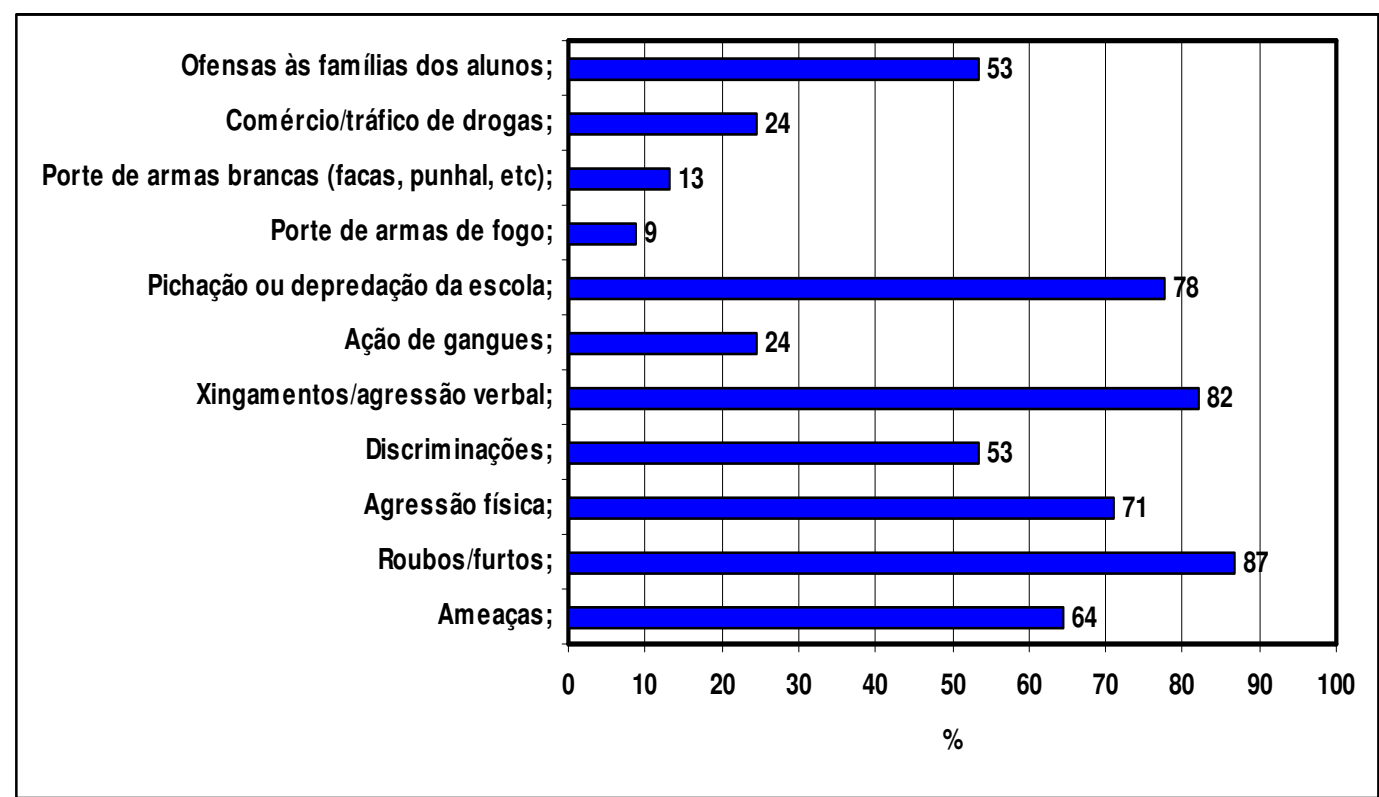

Fonte: Pesquisa de Campo, 02/06/2009, Geilson dos Santos Sales

\footnotetext{
${ }^{9}$ Nota: Foi perguntado aos alunos - Marque tudo que você sabe que acontece atualmente ou que aconteceu na sua escola entre 2008 e 2009.
} 
É um tipo de violência que é muito comum nas escolas, que envolve ameaças, agressão física entre os estudantes, roubos, furtos, tráfico de drogas e principalmente a pichação ou depredação da escola. Para $87 \%$ dos alunos afirmam que ocorre ou ocorreram roubos ou furtos na escola nos últimos anos. Outro tipo de violência é a questão dos xingamentos ou agressão verbal entre os estudantes, no qual cerca de $82 \%$ afirmam ocorrer isso na escola. Para 78\% dos alunos, a pichação ou depredação da escola é outro fato comum na escola, problema esse que afeta muitas escolas do Brasil. Já $71 \%$ dos estudantes entrevistados dizem na entrevista que a agressão é corriqueira no ambiente da escola.

GRÁFICO 7: Percentual de alunos que sofreram ações de violência na escola entre 2008 e $2009^{10}$

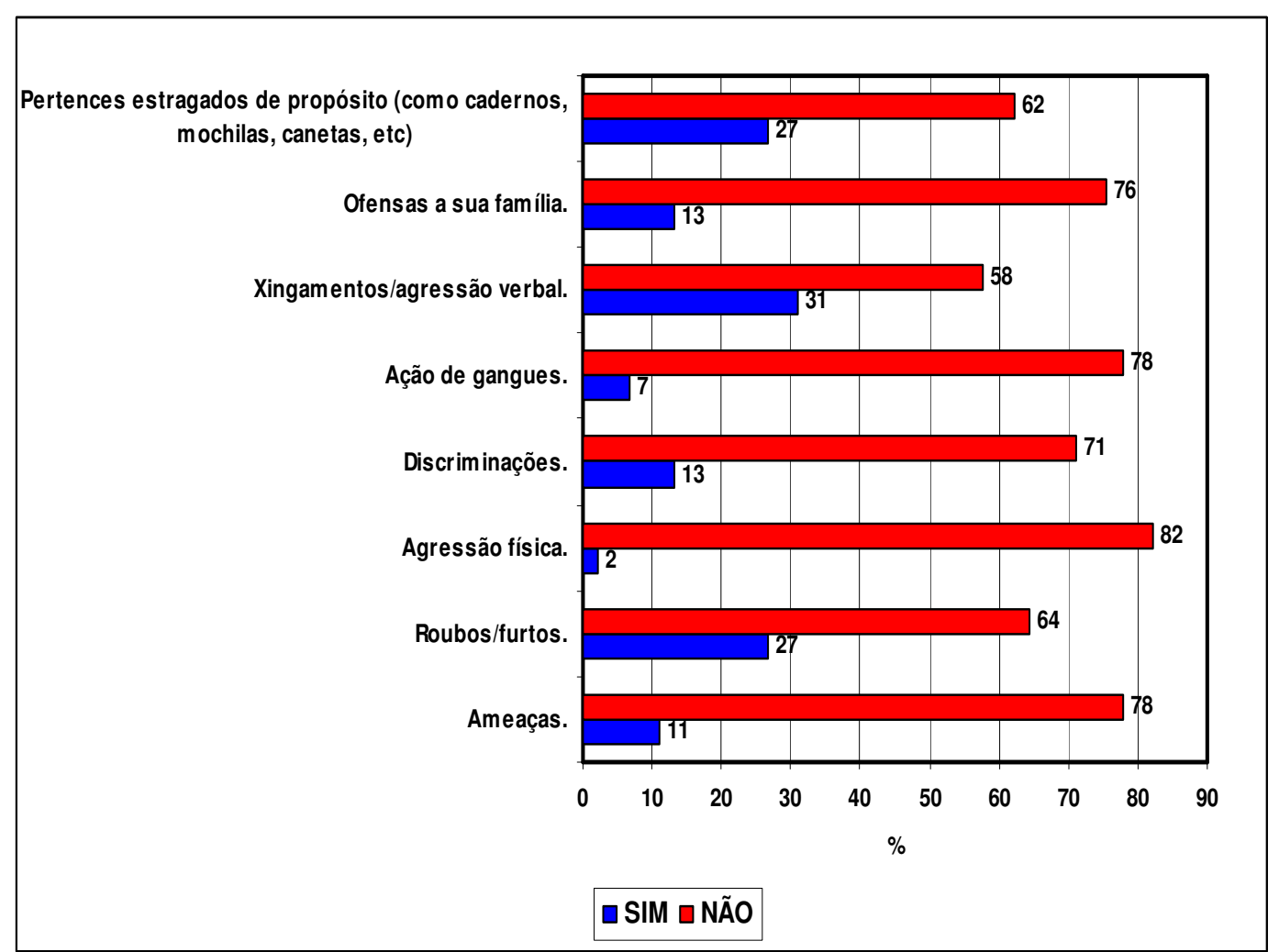

Fonte: Pesquisa de Campo, 02/06/2009, Geilson dos Santos Sales ${ }^{10}$ Nota: Foi perguntado aos alunos - Na sua escola, que tipo de agressão você já sofreu, no período
entre 2008 e 2009 ? 
Dos alunos entrevistados que já sofreram algum tipo de violência "dura", as mais comum são xingamentos ou agressão verbal, que corresponde por cerca de $31 \%$ dos alunos que já sofreram. Enquanto o roubo ou furtos, cerca de $27 \%$ dos entrevistados afirmam que já sofreram esse tipo de violência. Mas um fato geral da entrevista é que a maioria dos alunos entrevistados ainda não sofreram nenhum tipo de violência "dura". Já os estudantes que sofreram a violência de que seus pertencentes foram estragados de propósito, como as mochilas, os cadernos, as canetas, etc, corresponde a $27 \%$.

GRÁFICO 8: Percentual de alunos que praticaram ações de violência na escola entre 2008 e $2009^{11}$

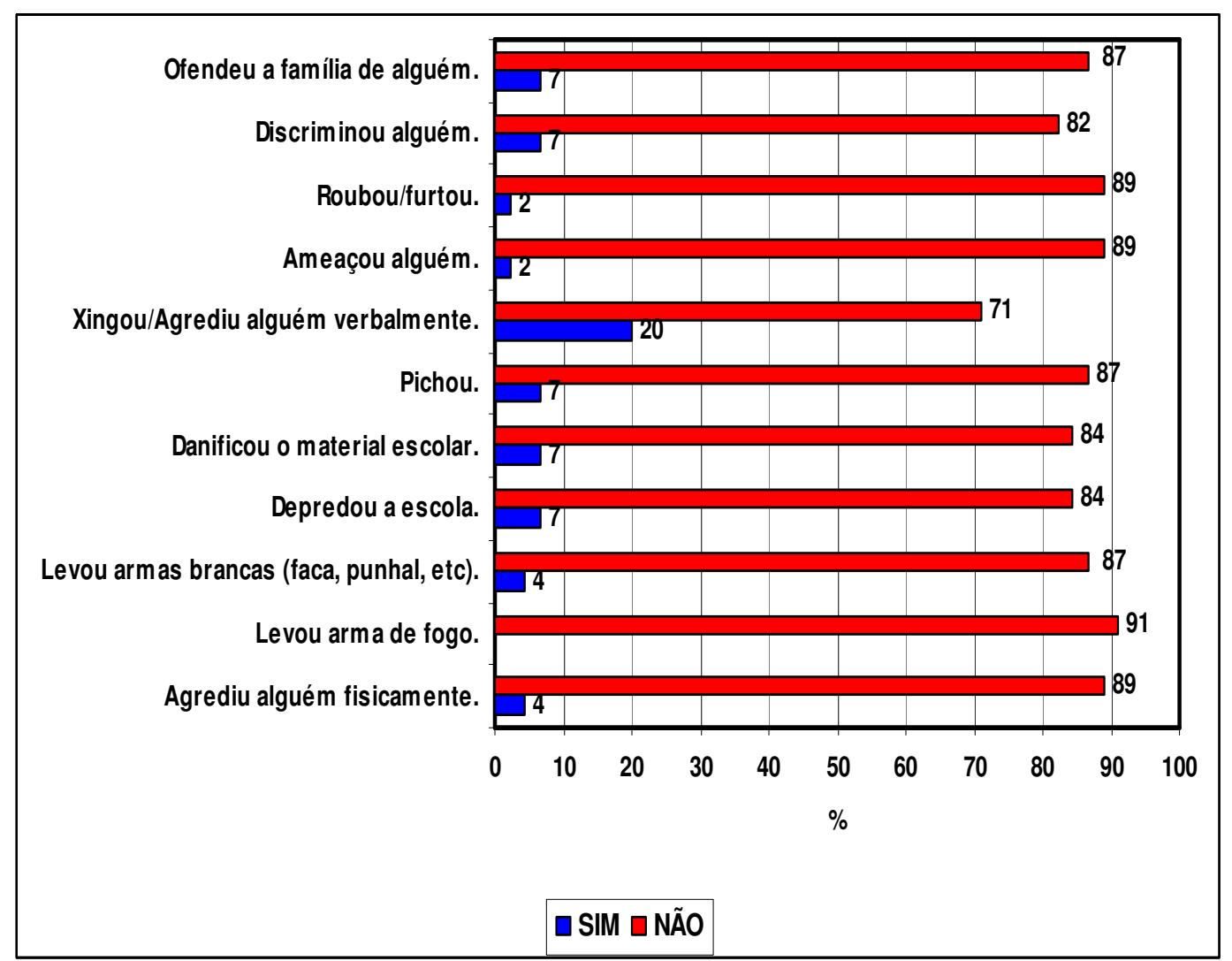

Fonte: Pesquisa de Campo, 02/06/2009, Geilson dos Santos Sales

${ }^{11}$ Nota: Foi perguntado aos alunos - Na sua escola, entre 2008 e 2009, você já: 
Dos alunos entrevistados, no qual foi perguntado se já praticaram alguma violência "dura". A violência mais comum praticada foi o xingamento e a agressão verbal, em que $20 \%$ dos entrevistados já praticaram. As outras ações como pichação ou depredação da escola, roubo e furtos aconteceram, mas em menor grau. Mas o fato é que para maioria dos entrevistados, não praticaram nenhum tipo de violência "dura".

\subsection{4 - A Violência Sexual}

GRÁFICO 9: Percentual de alunos que sabem o que aconteceu na escola entre 2008 e $2009^{12}$

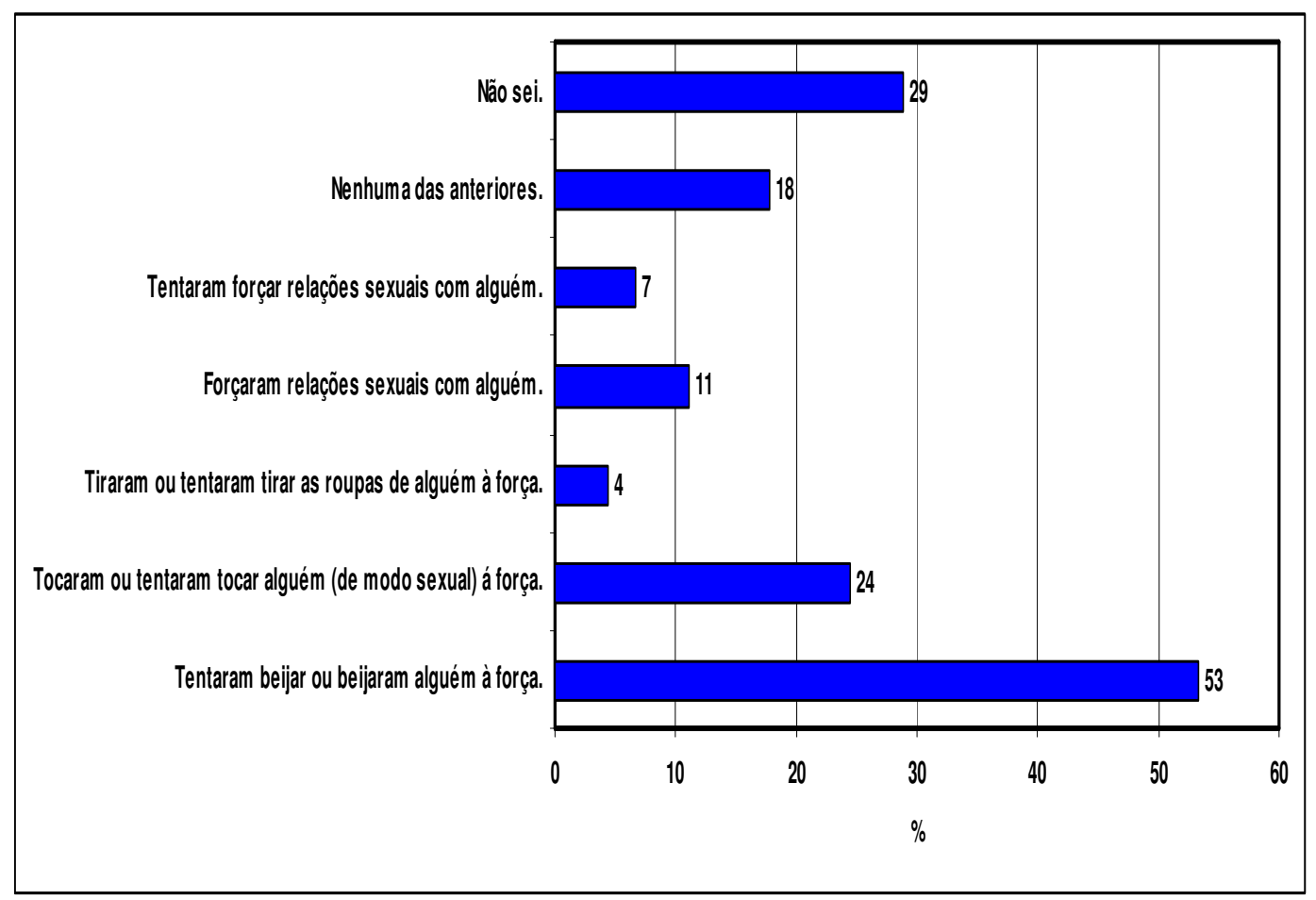

Fonte: Pesquisa de Campo, 02/06/2009, Geilson dos Santos Sales

\footnotetext{
12 Nota: Foi perguntado aos alunos - Marque tudo que você sabe que aconteceu ou já aconteceu na sua escola.
} 
Desse tipo de violência as mais comuns são a tentativa de beijar alguém à força, tocar alguém de modo sexual à força, tentar tirar a roupa de alguém sem permissão e a questão forçar relações sexuais com alguém. Na entrevista, de acordo com os alunos entrevistados, para 53\% o mais comum é tentar beijar alguém à força. Enquanto para $24 \%$ afirmam que acontece na escola a questão de tocar ou tentaram tocar em alguém de modo sexual à força. Um fato que os alunos afirmaram, cerca de $11 \%$ dos alunos, é que aconteceu de pessoas forçarem relações sexuais com alguém no interior da escola.

Esses dados apresentados correspondem às ações de violência que ocorre no Centro Educacional 123 em Samambaia, com alunos do Ensino Médio, com idades que variam de 15 a 17 anos.

3.4 - Os impactos e as conseqüências da violência

GRÁFICO 10: As conseqüiências da violência nos estudos ${ }^{13}$

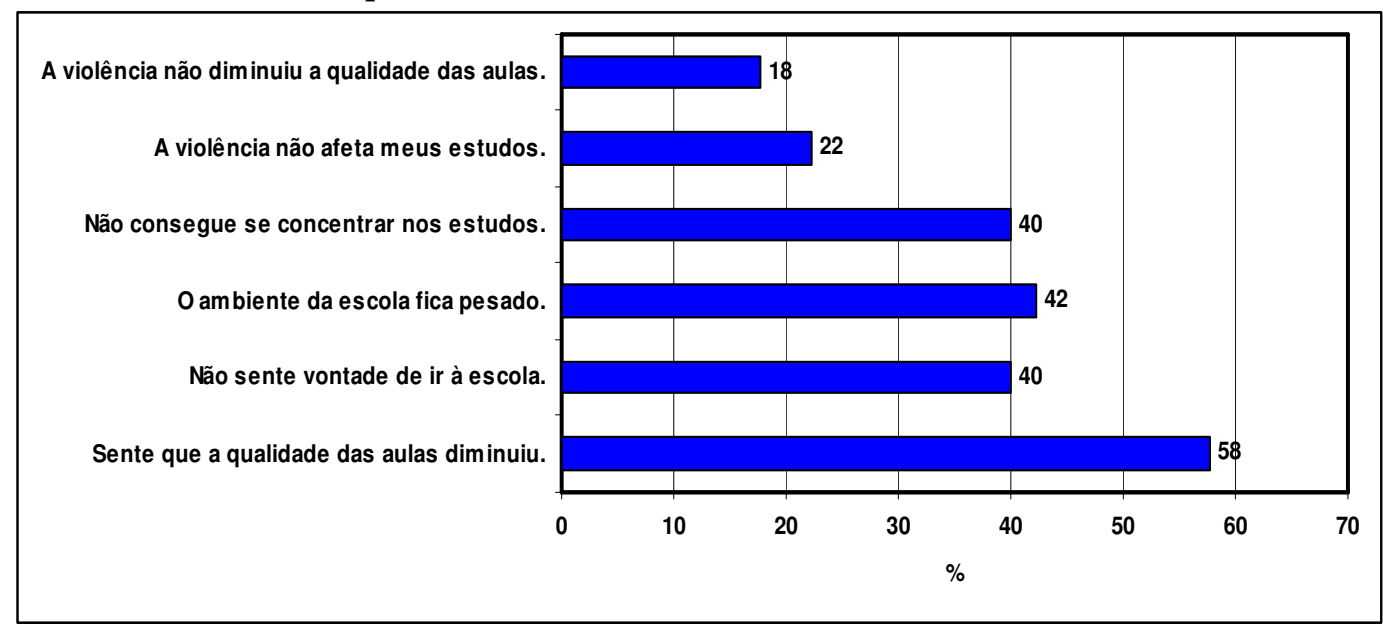

Fonte: Pesquisa de Campo, 02/06/2009, Geilson dos Santos Sales

${ }^{13}$ Nota: Foi perguntado aos alunos - Como você acha que a violência afeta seus estudos? 
De acordo com algumas pesquisas publicadas na mídia, no qual afirmam que a violência na escola gera sentimento de medo, ou seja, produz um impacto muito negativo sobre os estudantes, principalmente prejudicando a aprendizagem. De acordo com a entrevista, cerca de $58 \%$ dos estudantes afirmam que a qualidade das aulas diminui por causa da violência na escola. Enquanto $40 \%$ afirmam que não sentem vontade de ir à escola, já $42 \%$ dizem que o ambiente escolar fica pesado e outros $40 \%$ afirma que não conseguem se concentrar nos estudos.

\section{GRÁFICO 11: A percepção dos alunos sobre a escola ${ }^{14}$}

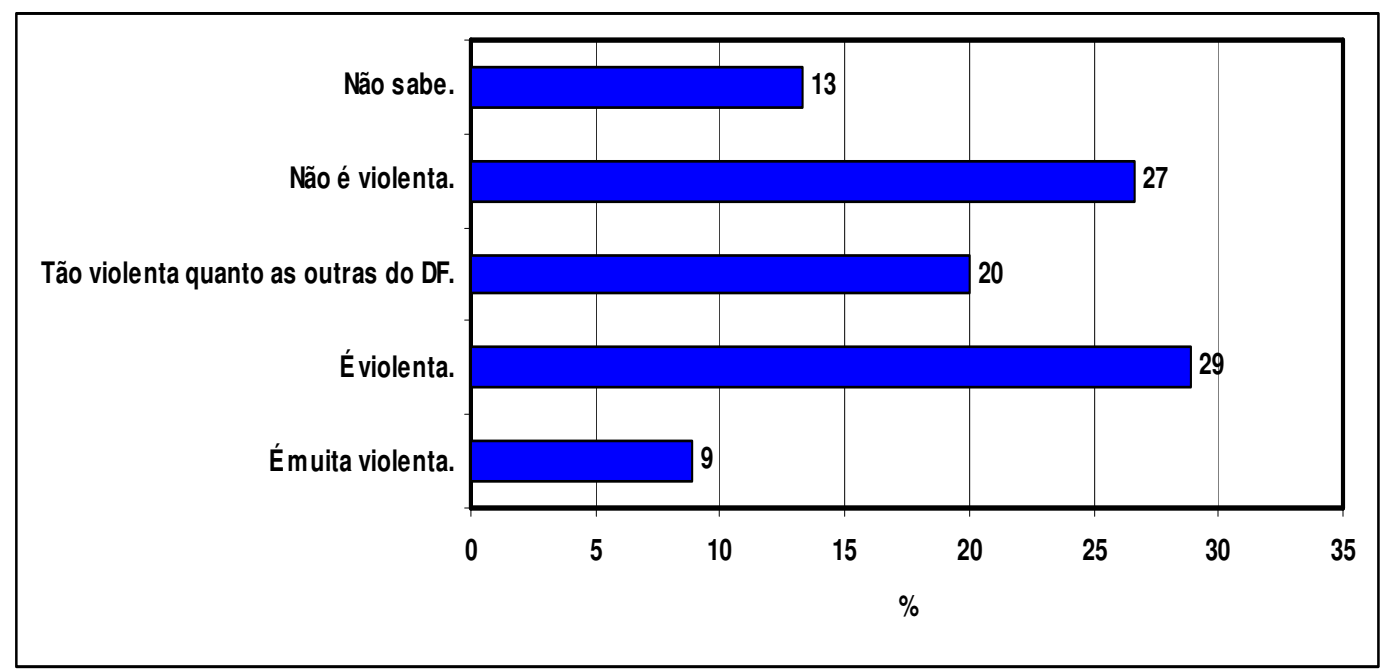

Fonte: Pesquisa de Campo, 02/06/2009, Geilson dos Santos Sales

Por último foi perguntado aos estudantes, se na opinião deles, a escola era violenta ou não. Cerca de $29 \%$ dos entrevistados afirma que acha a escola violenta, enquanto $20 \%$ consideram que a escola é tão violenta quanto outras do DF. Enquanto $27 \%$ dos entrevistados afirmam que a escola não é violenta.

\footnotetext{
${ }^{14}$ Nota: Foi perguntado aos alunos - Na sua opinião sobre a violência, sua escola:
} 
Os dados dessa pesquisa nos deram o panorama de uma situação que é muito comum nas escolas do Brasil, principalmente as escolas públicas. Essa pesquisa não mostra a fundo a questão da violência, mas mostra que ela existe e deve ser uma preocupação para toda a sociedade. 


\section{CONSIDERAÇÕES FINAIS}

A violência é um fenômeno que não é desprezível na transformação do espaço, como exemplo, o espaço da escola. O trabalho abordou muitos conceitos da violência, principalmente numa perspectiva geográfica.

Na Geografia, autores como (STEINBERGER E CARDOSO, 2005) abordam os conceitos de atores ou agentes, poder e território para definir o fenômeno violência. A questão da violência teria atores ou agentes e que eles utilizariam o poder e ao mesmo tempo suas ações se manifestariam no território. Enquanto (FERREIRA e PENNA, 2005) defendem a idéia do "Território da violência", ou seja, a seleção do espaço cria territórios abandonados pelo poder público, que são suscetíveis a ação de agentes externos, como por exemplo, a ação de gangues, de traficantes, etc. Esses agentes muitas vezes agem de maneira violenta no território para impor seu poder.

O entendimento da violência na escola deve levar em consideração que a escola possui atores ou agentes, como por exemplo, os alunos, os diretores, os professores, ou seja, toda a comunidade envolvida diretamente com a instituição escolar e que são atores nesse processo. E que esses atores possuem poder para agir dentro ou fora da escola. Esse poder poderia ser usado de forma negativa, como por exemplo, a depredação do ambiente físico da escola ou agredir fisicamente ou emocionalmente os membros da escola. Ou usar positivamente, como exemplo, para mudar a realidade nas escolas do Brasil ou do Distrito Federal, ou seja, diminuir a violência nas escolas.

A escola possui também um território sob sua influência. No caso do Centro Educacional 123 em Samambaia, seria o território das quadras 123 e 125. A região é muito carente em Samambaia. A escola possui o poder de modificar o seu território ou pode acontecer também o contrário, ou seja, o território sendo violento pode influenciar no ambiente da escola e tornar a escola num ambiente violento. $\mathrm{O}$ fato é que existe esse elo entre o território e a instituição "escola". 
A partir da pesquisa realizada no Centro Educacional 123 em Samambaia e analisada no Capítulo 2, a violência é um fenômeno freqüente na escola. A pesquisa confirma o estudo que a Secretaria de Educação do Distrito Federal realizou sobre a violência nas escolas públicas do DF. Quanto suas causas, o estudo bibliográfico apresenta diversas situações que podem influenciar na manifestação da violência na escola.

Sobre à manifestação desse fenômeno, ocorre de múltiplas formas, assim como (CHARLOT, 2002 apud CUBAS, 2006, p. 49) havia classificado a violência escolar como: na escola, à escola e da escola. A pesquisa ajudou a explicitar de formas mais clara como a violência se apresenta no meio dos estudantes.

De acordo com a pesquisa da Microviolência os tipos mais comuns de violência são o deboche ou zoação contra colegas na escola e a humilhação que é muito comum na escola, ou seja, pode-se considerar que o bullying acontece na escola. Da Violência Simbólica os tipos mais comuns são a discriminação por causa da região onde a pessoa mora, por causa que a pessoa é pobre, por causa também, que a pessoa segue uma determinada religião e por também por a pessoa ser ou parecer homossexual.

Sobre a Violência "dura" os tipos de violência que acontece na escola são o roubo ou furtos, que $87 \%$ dos alunos afirmam isso; o xingamento ou agressão verbal, segundo $82 \%$ dos estudantes, acontece na escola; cerca de $78 \%$ dos alunos afirmam que a pichação ou depredação da escola é comum no ambiente da escola. Depois vêm outros problemas como as ameaças, a ofensa às famílias dos alunos e a agressão física.

Quanto á Violência Sexual é comum na escola, de acordo com a pesquisa, a tentativa de beijar ou beijaram alguém à força, que 53\% afirmam isso e tocar ou tentaram tocar alguém de modo sexual à força. Esses são os tipos de violência que ocorre na escola por isso os afirmaram na pesquisa que consideram a escola violenta ou tão violenta quanto às outras escolas do Distrito Federal. 


\section{REFERÊNCIA BIBLIOGRÁFICA}

- ABRAMOVAY, Miriam (Coordenadora). Cotidiano das Escolas: entre violências. Edição: UNESCO Brasil - Brasília, 2006;

- ABRAMOVAY, Miriam e RUA, Maria das Graças. Violência nas escolas. UNESCO - Brasíllia, 2002, 400 p;

- AMORIM, Ricardo e POCHMANN, Márcio. Atlas da Exclusão Social no Brasil. Editora: Cortez, 2003, 2a edição;

- CODEPLAN:

.http://www.codeplan.gdf.gov.br/pdad;

. CUBAS, Viviane. Violência nas escolas: como defini-la. In: Violência na Escola: um guia para pais e professores. Organizadores: Caren Ruotti, Renato Alves, Viviane Cubas. Editora: Imprensa Oficial de São Paulo, 2006;

- FERREIRA, Ignez Costa Barbosa e PENNA, Nelba Azevedo. Território da Violência. In: Brasília: Dimensões da Violência Urbana, 2005. Organizadores: Aldo Paviani, Ignez Costa Barbosa Ferreira e Frederico Flósculo Pinheiro Barreto;

- IBGE: .http://www.ibge.gov.br/censodemografico2000;

. MICHAUD, Yves. A Violência. Editora: Ática, 2001. Tradução: L. Garcia;

. POSTERLI, Renato. Violência Urbana: abordagem multifatorial da criminogênese. Editora Inédita, 2000. Belo Horizonte; 
. ODALIA, Nilo. O que é Violência?. Editora: Brasiliense, Coleção Primeiros Passos, 1983;

- PAREDES, Eugênia Coelho; SAUL, Lea Lima e BIANCHI, Kátia Simone da Rosa. O que têm a dizer alunos e professores. Editora: FAPEMAT/EDO - UFMT, 2006.

. PINHEIRO, Paulo Sérgio e ALMEIDA, Guilherme Assis. Violência Urbana. Editora: Publifolha, 2003;

. SANTOS, Milton: O Espaço Dividido - Os dois circuitos da economia urbana dos países subdesenvolvidos. Editora: Livraria Francisco Alves Editora, 1979. Tradução: Myrna T. Rego Viana; . Natureza do Espaço: técnica e tempo, razão e emoção. Editora: Hucitec, São Paulo, 1996, 519 p.

. STEINBERGER, Marília e CARDOSO, Ana Izabel. A Geopolítica da Violência. In: Brasília: Dimensões da Violência Urbana, 2005. Organizadores: Aldo Paviani, Ignez Costa Barbosa Ferreira e Frederico Flósculo Pinheiro Barreto;

. SECRETARIA DE EDUCAÇÃO - GDF .http://www.sedf.gov.br

- SOUZA, Cira. Brasil e o conflito social moderno: crescimento econômico e a distribuição de renda. Instituto T. Neves, 2001;

. WAISELFSZ, Júlio Jacobo. Mapa da Violência dos Municípios Brasileiros. Editora: Ministério da Justiça, 2008. 